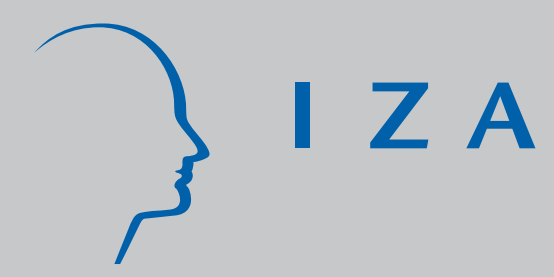

IZA DP No. 3712

The Rise and Fall of Spanish Unemployment: A Chain Reaction Theory Perspective

Marika Karanassou

Hector Sala

September 2008 


\title{
The Rise and Fall of Spanish Unemployment: A Chain Reaction Theory Perspective
}

\author{
Marika Karanassou \\ Queen Mary, University of London \\ and IZA \\ Hector Sala \\ Universitat Autònoma de Barcelona \\ and IZA \\ Discussion Paper No. 3712 \\ September 2008 \\ IZA \\ P.O. Box 7240 \\ 53072 Bonn \\ Germany \\ Phone: +49-228-3894-0 \\ Fax: +49-228-3894-180 \\ E-mail: iza@iza.org
}

\begin{abstract}
Any opinions expressed here are those of the author(s) and not those of IZA. Research published in this series may include views on policy, but the institute itself takes no institutional policy positions.

The Institute for the Study of Labor (IZA) in Bonn is a local and virtual international research center and a place of communication between science, politics and business. IZA is an independent nonprofit organization supported by Deutsche Post World Net. The center is associated with the University of Bonn and offers a stimulating research environment through its international network, workshops and conferences, data service, project support, research visits and doctoral program. IZA engages in (i) original and internationally competitive research in all fields of labor economics, (ii) development of policy concepts, and (iii) dissemination of research results and concepts to the interested public.
\end{abstract}

IZA Discussion Papers often represent preliminary work and are circulated to encourage discussion. Citation of such a paper should account for its provisional character. A revised version may be available directly from the author. 
IZA Discussion Paper No. 3712

September 2008

\section{ABSTRACT \\ The Rise and Fall of Spanish Unemployment: A Chain Reaction Theory Perspective*}

The evolution of Spanish unemployment has been quite idiosyncratic. The full employment levels of the early seventies were followed by unemployment rates that were the highest within the OECD countries in the aftermath of the oil price shocks. While unemployment was extremely persistent in most of the eighties and nineties, it experienced its sharpest decline in recent years. We investigate the determinants of this unemployment trajectory using the analytical framework of the chain reaction theory (CRT). We show that unemployment may not gravitate towards its natural rate due to frictional growth, a phenomenon that arises from the interplay of lagged adjustment processes and growing exogenous variables in a dynamic system with spillovers. The empirical analysis distinguishes four periods: (i) 1978-1985, (ii) 1986-1990, (iii) 1991-1994, (iv) 1995-2005, and finds that capital accumulation is a crucial driving force of unemployment. Thus, our theoretical and empirical results question the key role of the natural rate in policy making.

JEL Classification: E22, E24, J21

Keywords: labour market dynamics, frictional growth, chain reaction theory, capital accumulation, impulse response function

Corresponding author:

Hector Sala

Departament d'Economia Aplicada

Universitat Autònoma de Barcelona

08193 Bellaterra

Spain

E-mail: hector.sala@uab.es

\footnotetext{
* Hector Sala is grateful to the Spanish Ministry of Education and Science for financial support through grant SEJ2006-14849/ECON.
} 


\section{Introduction}

The evolution of Spanish unemployment over the past thirty five years has been unique among the OECD countries. The full-employment levels of the early seventies were, surprisingly, followed by the highest unemployment rates in the aftermath of the oil price shocks, and the most persistent unemployment problem in the eighties and nineties. The size and duration of high unemployment rates, in the range of around 10\%-20\% for approximately 20 years, have been dubbed the "Spanish disease" (Dolado and Jimeno, 1997). And somehow, Spain has again surprised by its rapid and prolonged unemployment rate decline over the second half of the nineties (the fall in unemployment of around 10 percentage points was the sharpest in the OECD area).

Figure 1 plots the unemployment rate trajectory by distinguishing four periods: (i) 1978-1985, (ii) 1986-1990, (iii) 1991-1994, and (iv) 1995-2005. ${ }^{1}$ Bentolila and Jimeno (2006) refer to the first one as the 'long recession', the next two as the 'EU cycle', and the last one as the 'EMU cycle'.

Figure 1. Unemployment rate

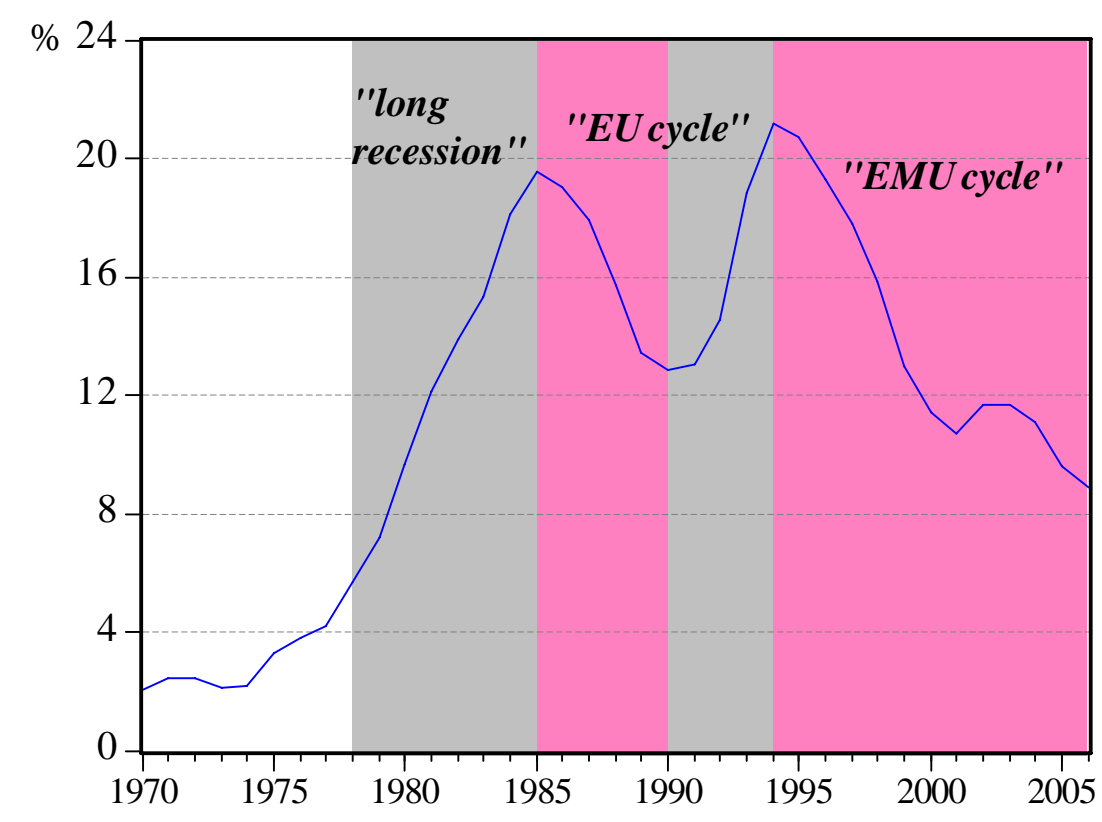

The consensus view is that a combination of labour unfriendly institutions (e.g. benefits) and adverse macroeconomic shocks (e.g. oil crises) were responsible for the development of the so-called "Spanish disease". Although the "usual suspects" such as wage-push

\footnotetext{
${ }^{1}$ Some studies use the Spanish labour market figures provided by the quarterly Survey of the Active Population (Encuesta de Población Activa, EPA), which underwent methodological changes in 1987, 1992, 2002, and 2005 (see Garrido and Toharia, 2004). Here we use the homogeneous long-time series provided by the OECD Economic Outlook, which slightly deviate from the EPA series.
} 
factors, taxes and stock-market swings do matter, we argue that the crucial driving force of unemployment is capital accumulation.

The conventional wisdom for the rise and fall of Spanish unemployment has evolved along the lines of the natural rate of unemployment, NRU (or NAIRU) ${ }^{2}$ story using a variety of methodologies. The econometric models include multi-equations à la Layard, Nickell and Jackman (1991), single-equations à la Phelps (1994), structural vector autoregressions (VARs), and the observable shocks model of Blanchard and Wolfers (2000).

Dolado, Malo de Molina and Zabalza (1986), using a structural multi-equation model, argue that the policies most suited to reducing unemployment without increasing inflation are lower taxation, a higher degree of labour market flexibility, and more effective incomes policies. Phelps and Zoega (2001) estimate a single-equation model for a panel of OECD countries and find that the long swings in economic activity result from the changes in expected future productivity, which can be proxied by the swings in the stock market. Spain appears as the most sensitive economy to these swings, although the omission of country-specific variables is acknowledged. Dolado and Jimeno (1997), using a structural VAR methodology, attribute the dismal performance of Spanish unemployment to a series of adverse shocks -"price shocks in the late 70s, wage shocks in the early 80s, and demand shocks in the early 90s' (p. 1285)- which were amplified by a rigid system of labour market institutions (e.g. collective bargaining, high firing costs, and barriers to competition in the goods market). Bentolila and Jimeno (2006), using the Blanchard and Wolfers (2000) model of equilibrium unemployment in the OECD, argue that Spain is characterised by a set of 'strongly unemployment generating' labour market institutions (i.e. unemployment benefits, employment protection, and collective bargaining) which aggravate the effects of adverse macroeconomic shocks.

In contrast to the above literature, this paper examines the Spanish labour market from the perspective of the CRT (chain reaction theory). The CRT uses dynamic structural multi-equation systems and postulates that the unemployment rate is driven by the interplay between interacting lagged adjustment processes and spillover effects. Spillovers arise when shocks to a specific equation feed through the labour market system, where "shocks" refer to changes in the exogenous variables.

The importance of having distinct equations for labour force and employment in the labour market model, rather than compressing them into a single-equation unemployment rate model, becomes evident from Figure 2. The disparity between the time paths of labour force and employment indicates that aggregating them into a single unemployment

\footnotetext{
${ }^{2}$ Tobin (1998) argues that the NAIRU (non accelerating inflation rate of unemployment) and NRU are not synonymous. However, within our context of analysis, such a distinction is superfluous. See Karanassou, Sala and Snower (2008) for a survey and critique of NAIRU and NRU models.
} 
rate equation will produce a biased summary of their evolution. ${ }^{3}$ According to Figure 2, labour force did not grow much in the seventies and early eighties. Although there was an acceleration in the second half of the eighties, it is since the mid nineties that this growth has been the fastest. On the other hand, employment figures show a much more procyclical behaviour.

\section{Figure 2. Employment, unemployment, and labour force}

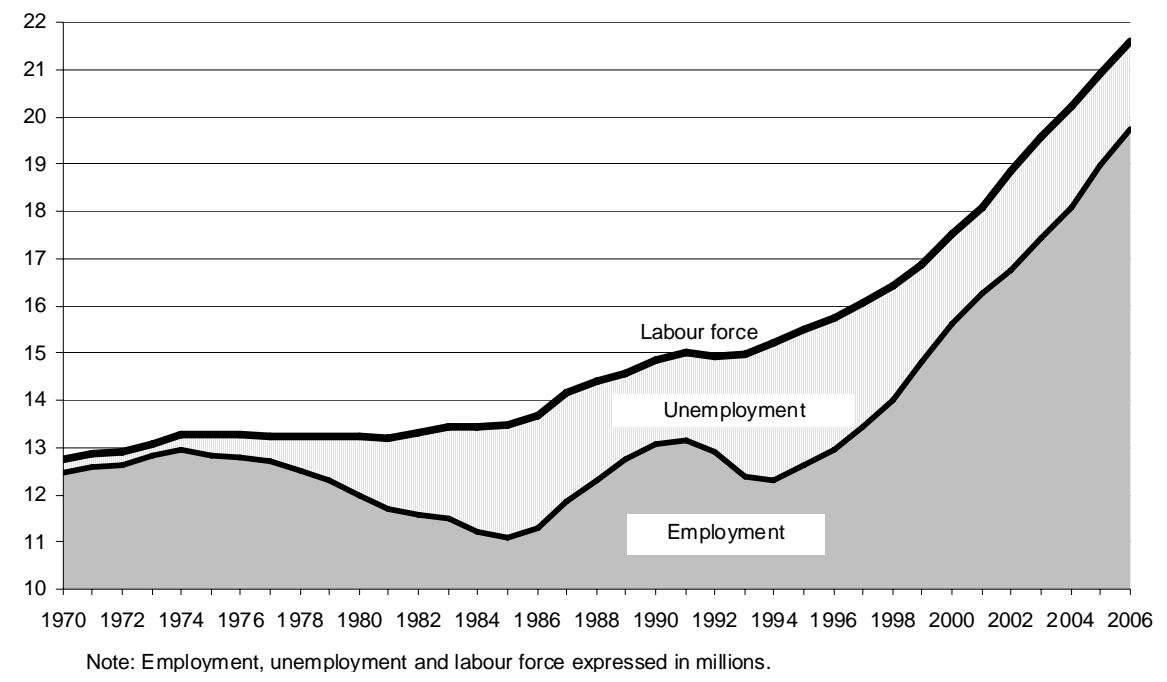

Generally, a CRT labour market model comprises labour demand, labour supply and wage setting equations. The system is dynamic due to the existence of adjustment costs which are well known in the literature. There are employment adjustment costs due to labour turnover costs, such as the costs of hiring and firing workers; wage setting costs due to nominal wage and price staggering; and labour force adjustment costs, due to monetary and psychic costs of entering and exiting the labour force. Spillovers are created when endogenous variables appear as explanatory variables in other equations (for example, wages in the labour demand and labour force equations, or the unemployment rate in the wage setting equation).

Each shock generates an intertemporal chain reaction of effects capturing the interplay between the dynamics and the spillovers of the system. These chain reactions are described in terms of impulse response functions. Therefore, the CRT represents a synthesis of traditional structural macroeconometric models and structural VARs.

Another important feature of the CRT is that it allows trended variables, such as capital stock, working-age population, or capital deepening, to influence unemployment. Unlike the NRU models, which impose strong a-priori restrictions, the CRT ensures that each equation is balanced (dynamically stable), so that each trended dependent variable

\footnotetext{
${ }^{3}$ For a comparison between multi-equation and single-equation unemployment rate approaches, see Karanassou, Sala and Snower (2003).
} 
is driven by the set of its trended determinants. This distinguishes the CRT from theories that just consider stationary variables as potential determinants of the trendless unemployment rate.

Finally, the interplay of lags (due to adjustment costs in labour market activities) and growing variables (due to the trended nature of the dependent variables) gives rise to the phenomenon of frictional growth. In the presence of frictional growth (FG), as we show in Section 2, long-run unemployment equals its NRU plus FG, and, consequently, unemployment cannot be decomposed into "trend" and cyclical components. In other words, since actual unemployment does not gravitate towards its natural rate, frictional growth challenges the central role attached by the mainstream theories to the NRU for explaining the rise and fall of unemployment.

Our empirical analysis of labour market dynamics shows that the growth rate of capital stock plays a crucial role in shaping unemployment movements during all the four periods portrayed in Figure 1. Although benefits, taxes, and financial wealth do influence unemployment, capital accumulation is the most substantial contributor to the unemployment trajectory.

The remaining of the paper is structured as follows. Section 2 analyses a stylised labour market model to convey the central features of the CRT. Section 3 provides a comprehensive overview of the Spanish experience in last decades. Section 4 is concerned with the econometric methodology and the estimated labour market system. The empirical model is used in Sections 5 and 6 to measure, respectively, the dynamic contributions of the exogenous variables to the evolution of unemployment, and the long-run impact of capital accumulation on the unemployment trajectory. Section 7 concludes.

\section{Chain Reaction Theory (CRT)}

To understand the development of the unemployment problem, the chain reaction theory advocates the use of interactive dynamic labour market models, i.e. dynamic multiequation systems with spillover effects. Spillovers arise when endogenous variables have explanatory power in other equations of the system. By chain reactions we refer to the intertemporal responses of the unemployment rate to changes in the exogenous variables ("shocks"). The chain reactions are generated by the interplay between the dynamics and spillovers of the system. The analytical model below illustrates the workings of the CRT and is in line with our estimated labour market model in Section 5. 


\subsection{A Stylised Labour Market Model}

Consider the following labour demand, real wage, and labour supply equations: ${ }^{4}$

$$
\begin{aligned}
n_{t} & =\alpha_{1} n_{t-1}+\beta_{1} k_{t}-\gamma_{1} w_{t}, \\
w_{t} & =\alpha_{2} w_{t-1}+\beta_{2} x_{t}-\gamma_{2} u_{t}, \\
l_{t} & =\beta_{3} z_{t}+\gamma_{3} w_{t}
\end{aligned}
$$

and let the unemployment rate be defined $\operatorname{as}^{5}$

$$
u_{t}=l_{t}-n_{t},
$$

where $u_{t}$ is the unemployment rate; $n_{t}, w_{t}$, and $l_{t}$ denote employment, real wage, and labour force, respectively; $k_{t}$ is real capital stock, $x_{t}$ represents a wage-push factor, and $z_{t}$ is working-age population; the $\beta$ 's, and $\gamma$ 's are positive constants. All variables, except the unemployment rate, are in logs and the error terms are ignored for expositional ease. The autoregressive parameters $\alpha_{1}$ and $\alpha_{2}$ are positive and less than unity, capturing the employment adjustment and wage/price staggering effects, respectively. Generally, we refer to the lags of the endogenous variables in a CRT model as the "lagged adjustment processes".

It is important to note that, unlike the single-equation NRU models, the CRT models may also include trended exogenous variables. The only requirement is that each equation is balanced (i.e. dynamically stable) so that each trended dependent variable is driven by the set of its trended determinants. It can be shown that equilibrating mechanisms in the labour market and other markets jointly act to ensure that the unemployment rate is trendless in the long-run (Karanassou and Snower, 2004). In terms of the above analytical model, these mechanisms can be expressed in the form of restrictions on the relationships between the long-run growth rates of the growing exogenous variables (see Section 2.4).

The $\gamma$ 's generate spillover effects, since changes in an exogenous variable in one equation, say capital stock in labour demand, can also affect the real wage and labour supply equations. Observe that if the wage elasticities are zero $\left(\gamma_{1}=\gamma_{3}=0\right)$, the wage-push factor $\left(x_{t}\right)$ does not influence unemployment. In addition, if unemployment does not put downward pressure on wages $\left(\gamma_{2}=0\right)$, changes in capital stock $\left(k_{t}\right)$ and working-age population $\left(z_{t}\right)$ do not spillover in the labour market system and so their unemployment effects can be adequately captured by the labour demand (1) and supply (3) equations. ${ }^{6}$

\footnotetext{
${ }^{4}$ It can be shown that the above labour market model is compatible with standard microeconomic foundations.

${ }^{5}$ Since labour force and employment are in logs, the unemployment rate can be approximated by their difference.

${ }^{6}$ This is because labour demand and labour supply are linked via wages. If changes in the capital stock
} 
Therefore, in the presence of spillover effects, the individual labour demand and supply equations cannot provide adequate measures of the sensitivities of unemployment to the exogenous variables. We refer to the $\beta$ 's as the "local" short-run elasticities in order to distinguish them from the "global" ones, which incorporate all the feedback mechanisms in the labour market model. The global elasticities can be obtained by the univariate representation of unemployment which we derive below. ${ }^{7}$

\subsection{Univariate Representation of Unemployment}

Rewrite the demand, wage, and supply equations (1)-(3) as

$$
\begin{aligned}
\left(1-\alpha_{1} B\right)\left(1-\alpha_{2} B\right) n_{t}= & \beta_{1}\left(1-\alpha_{2} B\right) k_{t}-\gamma_{1}\left(1-\alpha_{2} B\right) w_{t}, \\
\left(1-\alpha_{2} B\right) w_{t}= & \beta_{2} x_{t}-\gamma_{2} u_{t}, \\
\left(1-\alpha_{1} B\right)\left(1-\alpha_{2} B\right) l_{t}= & \beta_{3}\left(1-\alpha_{1} B\right)\left(1-\alpha_{2} B\right) z_{t}+ \\
& \gamma_{3}\left(1-\alpha_{1} B\right)\left(1-\alpha_{2} B\right) w_{t},
\end{aligned}
$$

where $B$ is the backshift operator, and substitute (6) into (5) and (7) to obtain the following equations for employment and labour force:

$$
\begin{aligned}
\left(1-\alpha_{1} B\right)\left(1-\alpha_{2} B\right) n_{t}= & \beta_{1}\left(1-\alpha_{2} B\right) k_{t}-\gamma_{1} \beta_{2} x_{t}+\gamma_{1} \gamma_{2} u_{t}, \\
\left(1-\alpha_{1} B\right)\left(1-\alpha_{2} B\right) l_{t}= & \beta_{3}\left(1-\alpha_{1} B\right)\left(1-\alpha_{2} B\right) z_{t}+ \\
& \gamma_{3} \beta_{2}\left(1-\alpha_{1} B\right) x_{t}-\gamma_{3} \gamma_{2}\left(1-\alpha_{1} B\right) u_{t}
\end{aligned}
$$

respectively.

The univariate representation (or reduced form dynamics) of the unemployment rate can be obtained by inserting the above equations into (4): ${ }^{8}$

$$
\begin{aligned}
{\left[\left(1-\alpha_{1} B\right)\left(1-\alpha_{2} B\right)+\gamma_{3} \gamma_{2}\left(1-\alpha_{1} B\right)+\gamma_{1} \gamma_{2}\right] u_{t}=} & -\beta_{1}\left(1-\alpha_{2} B\right) k_{t} \\
& +\gamma_{3} \beta_{2}\left(1-\alpha_{1} B\right) x_{t}+\gamma_{1} \beta_{2} x_{t} \\
& \beta_{3}\left(1-\alpha_{1} B\right)\left(1-\alpha_{2} B\right) z_{t} .
\end{aligned}
$$

The term "reduced form" relates to the fact that the parameters of the equation are not estimated directly, instead, they are some nonlinear function of the parameters of the

and working-age population do not influence wages $\left(\gamma_{2}=0\right)$ they cannot spillover to the system. The individual labour demand and supply equations can sufficiently capture their effects on unemployment.

${ }^{7}$ The univariate representation expresses unemployment as a function of it own lags and the exogenous variables in the system.

${ }^{8}$ Note that (10) is dynamically stable since (i) products of polynomials in $B$ which satisfy the stability conditions are stable, and (ii) linear combinations of dynamically stable polynomials in $B$ are also stable. 
underlying labour market system (1)-(3).

We can reparameterise the above equation as

$$
\begin{aligned}
u_{t}= & \phi_{1} u_{t-1}-\phi_{2} u_{t-2}-\theta_{k} k_{t}+\theta_{x}\left(\gamma_{1}+\gamma_{2}\right) x_{t}+\theta_{z} z_{t}+ \\
& \alpha_{2} \theta_{k} k_{t-1}-\alpha_{1} \gamma_{3} \theta_{x} x_{t-1}-\left(\alpha_{1}+\alpha_{2}\right) \theta_{z} z_{t-1}+\alpha_{1} \alpha_{2} \theta_{z} z_{t-2},
\end{aligned}
$$

where $\phi_{1}=\frac{\alpha_{1}+\alpha_{2}+\alpha_{1} \gamma_{2} \gamma_{3}}{1+\gamma_{1} \gamma_{2}+\gamma_{2} \gamma_{3}}, \phi_{2}=\frac{\alpha_{1} \alpha_{2}}{1+\gamma_{1} \gamma_{2}+\gamma_{2} \gamma_{3}}, \theta_{k}=\frac{\beta_{1}}{1+\gamma_{1} \gamma_{2}+\gamma_{2} \gamma_{3}}, \theta_{x}=\frac{\beta_{2}}{1+\gamma_{1} \gamma_{2}+\gamma_{2} \gamma_{3}}$, and $\theta_{z}=\frac{\beta_{3}}{1+\gamma_{1} \gamma_{2}+\gamma_{2} \gamma_{3}}$.

The univariate representation (11) shows that unemployment is generated by the interplay of lagged adjustment processes and spillovers. In particular, the autoregressive coefficients $\phi_{1}$ and $\phi_{2}$ embody the interactions of the employment adjustment $\left(\alpha_{1}\right)$ and wage-price staggering $\left(\alpha_{2}\right)$ processes. The $\theta$ 's embody the feedback mechanisms built in the system, since they are a function of the semi-elasticities $(\beta$ 's) of the individual equations (1)-(3) and the spillovers ( $\gamma$ 's). Thus, the $\theta$ 's describe the "global" short-run sensitivities of unemployment with respect to the exogenous variables. The interplay of dynamics across equations is further emphasized by the lagged structure of the exogenous variables. Using time series jargon, we refer to the lagged exogenous variables as "moving-average" terms.

Another key element of the CRT is that capital stock, a trended variable, influences the time path of the unemployment rate, a stationary variable. We can justify this result as follows. Capital stock initially enters the system as a determinant of employment, a trended variable. Labour demand (1) is a balanced equation since it is dynamically stable $\left(\left|\alpha_{1}\right|<1\right)$. Similarly, the trended labour force is driven by working-age population (also a trended variable), and the static labour supply (3) is itself a balanced equation. According to (8)-(9), the labour demand and supply equations remain balanced once the wage (2) has been substituted into them. ${ }^{9}$

\subsection{Impulse Response Functions}

The responses of unemployment through time $\left(R_{t+j}, j \geq 0\right)$ to a one-off unit shock (impulse), occurring at period $t$, are described by the impulse response function (IRF) of its univariate representation (11). Unemployment persistence $(\sigma)$ can be defined as the sum of its future responses, i.e. for all periods in the aftermath of the shock: ${ }^{10} \sigma \equiv \sum_{j=1}^{\infty} R_{t+j}$.

Note that the responses can be interpretted as the "global" elasticities (strictly speaking, semi-elasticities or slopes) of the unemployment rate, since shocks in the CRT refer

\footnotetext{
${ }^{9}$ Note that (8) and (9) are dynamically stable since the products of polynomials in $B$ which satisfy the stability conditions are also stable.

${ }^{10}$ Other measures of persistence are the half life of the shock, the sum of the autoregressive parameters, and the largest autoregressive root.
} 
to changes in the exogenous variables. In particular, the contemporaneous response $\left(R_{t}\right)$ captures the "global" short-run elasticity, whereas the sum of all responses measures the "global" long-run elasticity. In other words, the short-run elasticity plus persistence equals the long-run elasticity of the specific variable:

$$
\begin{aligned}
& \text { long-run elasticity }=\text { short-run elasticity }+ \text { persistence } \\
& \sum_{j=0}^{\infty} R_{t+j} \quad R_{t} \quad \sum_{j=1}^{\infty} R_{t+j}
\end{aligned}
$$

Furthermore, we can measure the contributions of an exogenous variable, say $x$, to the evolution of unemployment over a specific period of time, say $t=0$ to $t=T$, by sequentially adding up the IRFs of the respective changes during the specific period. Let $\Delta x_{j}=x_{j}-x_{j-1}$, where $j=1,2, \ldots T$, and $\Delta$ is the first difference operator. The IRFs of these $T$ shocks are:

$$
\begin{array}{ccccc} 
& t=1 & t=2 & \ldots & t=T \\
\mathrm{IRF}_{1}: & R_{11} & R_{12} & \ldots & R_{1 T} \\
\mathrm{IRF}_{2}: & - & R_{22} & \ldots & R_{2 T} \\
\ldots & - & - & \ldots & \ldots \\
\mathrm{IRF}_{T}: & - & - & \ldots & R_{T T}
\end{array}
$$

where $\mathrm{IRF}_{j}$ denotes the response function to the $j$ th shock, and $R_{j t}$ is the response to shock $j$ in time $t$. Note that the diagonal elements denote the respective contemporaneous responses to the various shocks.

We measure the $t$-period contribution as the sum of all responses at this period. Therefore, the contributions of the exogenous variable $x$ to the unemployment trajectory for the given interval are given by the following time series:

$$
\begin{array}{ccccc}
t=1 & t=2 & t=3 & \ldots & t=T \\
R_{11}, & \sum_{j=1}^{2} R_{j 2}, & \sum_{j=1}^{3} R_{j 3}, & \ldots & \sum_{j=1}^{T} R_{j T} .
\end{array}
$$

An important drawback of the traditional structural macroeconometric models is that the IRFs are missing from their analysis. This is because the plethora of spillover effects in the system can substantially affect the size and sign of the "local" elasticities so that the individual equations can be quite misleading regarding the effects of the exogenous variables on unemployment. By focusing on the IRFs of the system, (structural) VARs offer a statistically robust alternative. Unlike the traditional macroeconometric models, the CRT emphasizes the role of IRFs in its investigation and uses the global elasticities as a misspecification tool to diagnose the economic plausibility of the model. Thus, the CRT methodology can be viewed as a synthesis of the traditional structural macroeconometric 
models and the (structural) VARs.

\subsection{Frictional Growth}

In what follows, we show that in the CRT framework of analysis unemployment may substantially deviate in both the short- and long-run from what is commonly perceived as its natural rate. This was first pointed out by Karanassou and Snower (1997) and opposes the conventional wisdom that the NRU is the attractor of the unemployment rate.

We demonstrate this result by making the plausible assumption that capital stock $\left(k_{t}\right)$ and working age population $\left(z_{t}\right)$ are growing variables with growth rates that stabilise in the long-run. We also assume, for simplicity and without loss of generality, that the wage-push factor $\left(x_{t}\right)$ does not grow in the long-run. Note that the growth rates of log variables are proxied by their first differences, $\Delta(\cdot)$, and the superscript ${ }^{L R}$ denotes the long-run value of the variable.

The unemployment definition (4) implies that the unemployment rate stabilises in the long-run, $\Delta u^{L R}=0$, if the growth rate of employment is equal to the growth rate of labour force, say $\lambda$,

$$
\Delta l^{L R}=\Delta n^{L R}=\lambda
$$

The above restriction can also be expressed in terms of the long-run growth rates of the exogenous variables:

$$
\frac{\beta_{1}}{1-\alpha_{1}} \Delta k^{L R}=\Delta z^{L R}
$$

We refer to (15) as the frictional growth $(F G)$ stability condition, since it ensures that the unemployment rate stabilises in the long-run.

Let us reparameterise the demand (1) and wage equations (2) as

$$
\begin{aligned}
n_{t} & =\frac{\beta_{1}}{1-\alpha_{1}} k_{t}-\frac{\gamma_{1}}{1-\alpha_{1}} w_{t}-\frac{\alpha_{1}}{\left(1-\alpha_{1}\right)} \Delta n_{t}, \\
w_{t} & =\frac{\beta_{2}}{1-\alpha_{2}} x_{t}-\frac{\gamma_{2}}{1-\alpha_{2}} u_{t}-\frac{\alpha_{2}}{\left(1-\alpha_{2}\right)} \Delta w_{t}
\end{aligned}
$$

respectively. Next, substitute the wage eq. (17) into the demand (16) and supply equations (3):

$$
\begin{aligned}
n_{t}= & \frac{\beta_{1}}{1-\alpha_{1}} k_{t}-\frac{\gamma_{1} \beta_{2}}{\left(1-\alpha_{1}\right)\left(1-\alpha_{2}\right)} x_{t}+\frac{\gamma_{1} \gamma_{2}}{\left(1-\alpha_{1}\right)\left(1-\alpha_{2}\right)} u_{t} \\
& +\frac{\gamma_{1} \alpha_{2}}{\left(1-\alpha_{1}\right)\left(1-\alpha_{2}\right)} \Delta w_{t}-\frac{\alpha_{1}}{\left(1-\alpha_{1}\right)} \Delta n_{t}, \\
l_{t}= & \beta_{3} z_{t}+\frac{\gamma_{3} \beta_{2}}{1-\alpha_{2}} x_{t}-\frac{\gamma_{3} \gamma_{2}}{1-\alpha_{2}} u_{t}-\frac{\gamma_{3} \alpha_{2}}{1-\alpha_{2}} \Delta w_{t}
\end{aligned}
$$


Substitution of the above equations into (4) and some algebraic manipulation yields the following expression for the unemployment rate:

$u_{t}=\frac{1}{\zeta}\left[\beta_{3} z_{t}-\frac{\beta_{1}}{1-\alpha_{1}} k_{t}+\frac{\left(1-\alpha_{1}\right) \gamma_{3} \beta_{2}+\gamma_{1} \beta_{2}}{\left(1-\alpha_{1}\right)\left(1-\alpha_{2}\right)} x_{t}\right]+\frac{1}{\zeta}\left[\frac{\alpha_{1}}{\left(1-\alpha_{1}\right)} \Delta n_{t}-\frac{\left(1-\alpha_{1}\right) \gamma_{3} \alpha_{2}+\gamma_{1} \alpha_{2}}{\left(1-\alpha_{1}\right)\left(1-\alpha_{2}\right)} \Delta w_{t}\right]$,

where $\zeta=\left(1+\frac{\gamma_{1} \gamma_{2}}{\left(1-\alpha_{1}\right)\left(1-\alpha_{2}\right)}-\frac{\gamma_{3} \gamma_{2}}{1-\alpha_{2}}\right)$.

The above leads to the following unemployment rate equation in the long-run:

$$
u^{L R}=\frac{1}{\zeta}[\underbrace{\left(\beta_{3} z^{L R}-\frac{\beta_{1}}{1-\alpha_{1}} k^{L R}+\frac{\left(1-\alpha_{1}\right) \gamma_{3} \beta_{2}+\gamma_{1} \beta_{2}}{\left(1-\alpha_{1}\right)\left(1-\alpha_{2}\right)} x^{L R}\right)}_{\text {natural rate of unemployment }}+\underbrace{\frac{\alpha_{1} \beta_{1}}{\left(1-\alpha_{1}\right)^{2}} \Delta k^{L R}}_{\text {frictional growth }}],
$$

since $\Delta n^{L R}=\frac{\beta_{1}}{1-\alpha_{1}} \Delta k^{L R}$ and $\Delta w^{L R}=0$. The first term of (21) gives the NRU, whereas the second term of (21) captures frictional growth. Note that when the exogenous variables have nonzero long-run growth rates, unemployment is trendless in the long-run under the FG stability condition (15).

According to (20), if the growth rate of employment is zero in the long-run $\left(\Delta n^{L R}=0\right)$, the first term of (20) in square brackets is the "trend" component of unemployment, while the second term in square brackets is its cyclical component (since it is zero in the longrun). However, under frictional growth, this decomposition cannot be obtained. This distinguishes the CRT from models which filter out the cyclical variations of unemployment (e.g. using 5-year averages) and then identify its driving forces.

The long-run value $\left(u^{L R}\right)$ towards which the unemployment rate converges reduces to the NRU only when frictional growth is zero. In the above CRT model this occurs if (i) the long-run growth rate of capital stock is zero or (ii) the lagged adjustment effect is zero $\left(\alpha_{1}=0\right)$. Therefore, frictional growth implies that under quite plausible conditions the natural rate is not an attractor of the moving unemployment, and so the relevance of the NRU in policy making is questionable. ${ }^{11}$ Reliance on natural rate estimates without taking into account the impact of FG may, for example, lead to a misjudgment of the unemployment effects of labour market reforms.

\subsection{Long-run, Natural Rate, Contributions}

To sum up, the interplay between lagged adjustment processes and growing exogenous variables generates frictional growth, which has the following implications.

\footnotetext{
${ }^{11}$ For example, Karanassou and Sala (2008a) find that the NRU explains only $33 \%$ of the unemployment variation in Denmark, while frictional growth accounts for the remaining $67 \%$.
} 
- The NRU is not a reference point for the actual unemployment rate:

$$
\text { long-run }=\underset{\text { (steady-state })}{\mathrm{NRU}}+\text { frictional growth }
$$

- Unemployment cannot be decomposed into "trend" and cyclical components. This is in contrast with the standard NRU models: ${ }^{12}$

$$
u_{t}=\alpha u_{t-1}+\beta x_{t} \text { or } u_{t}=\underbrace{\frac{\beta}{1-\alpha} x_{t}}_{\text {"trend" or NRU }}-\underbrace{\frac{\alpha}{1-\alpha} \Delta u_{t}}_{\text {cyclical }},
$$

since, by construction $\Delta u^{L R}=0$.

- Since the unemployment rate is trendless, NRU models assert that growing variables can only influence the labour market via their trendless transformations. Unlike NRU models, the CRT models may also include trended exogenous variables. The only requirement is that each equation is balanced (i.e. dynamically stable) so that each trended dependent variable is driven by the set of its trended determinants. Consequently, the univariate representation of unemployment is itself balanced and the frictional growth stability condition (14) ensures that the unemployment rate stabilises in the long-run

As we argued above, there may be a substantial disparity between the long-run and natural rates of unemployment due to frictional growth. Our limited knowledge of the long-run values of the growth rates of the exogenous variables implies that we do not have reliable estimates of frictional growth, and consequently of the long-run unemployment rate.

Thus, CRT models do not attempt to determine the factors underlying the natural (or long-run) unemployment rate. Instead, the focus is on the contributions of the exogenous variables to the evolution of the unemployment rate, which were defined by equation (13).

\subsection{CRT, NRU, and Hysteresis}

In what follows we briefly compare and contrast the chain reaction, natural rate, and hysteresis theories of unemployment. ${ }^{13}$

- The short-run (cyclical) and long-run (natural) unemployment rates are

\footnotetext{
${ }^{12}$ The $\mathrm{AR}(1)$ model is used for expositional ease.

${ }^{13}$ See Karanassou, Sala, and Snower (2008) for a comprehensive survey and critique of the NRU and hysteresis theories.
} 
- interdependent in CRT models

- compartmentalised in NRU and hysteresis models.

- The effects of temporary shocks on unemployment

- dissipate through time in CRT and NRU models

- propagate to its natural rate in hysteresis models.

- While CRT and NRU models can identify the driving forces of the unemployment rate, hysteresis models simply offer statistical representations of its trajectory.

- Whereas CRT estimates a labour market system and then derives the univariate representation of the unemployment rate, NRU single-equation models estimate a reduced-form unemployment rate equation.

It is worthwhile pointing out that linearity is the common ground for all three theories, i.e. the unemployment rate process in NRU, hysteresis, and CRT models responds to shocks in a linear fashion. The hysteresis theory in the above discussion refers only to the popular "unit root hysteresis". It is beyond the scope of this paper to discuss hysteretic models which display remanence, i.e. positive and negative shocks of equal size do not cancel out. This type of hysteresis involves economic models with heterogeneous agents who respond nonlinearly to shocks (Cross et al., 1999).

\section{Overview of the Spanish experience}

Spain enjoyed a long situation of full employment throughout the fifties and sixties lasting until 1977. A central feature of the unemployment trajectory is its persistence in the sense that, in the last three decades, it has never recovered the full-employment situation of the past. Table 1 summarises the numerous institutional and labour market related policy changes experienced by the Spanish economy in the aftermath of the Francoist period. 
Table 1: Institutional and policy changes

Labour market changes:

1980:

1977-1986:

1984:

1984:

1992:

1994:

1997:

2001:

2002:

2006:
Worker's Statute

Incomes policies

First UB reform

First labour market reform

Second UB reform

Second labour market reform

Third labour market reform

Fourth labour market reform

Third UB reform

Other institutional changes:

1977: Democracy

1977: Moncloa Pacts

1978: Spanish Constitution

1986: Entry into the EEC

1989: Entry into the EMS

1992: Maastricht Treaty signed

1994: Bank of Spain independence

1999: Entry into EMU

1999: Stability and growth pact

Below we discuss these labour market features, other institutional changes mainly related to the European integration process, and the specific macroeconomic features across business cycles that have accompanied the rise and fall of the Spanish unemployment rate.

\subsection{Institutional Features}

The main issues of interest in the labour market are the wage bargaining system, the implementation of a set of incomes policies in 1977-1986, and the legislation on employment and unemployment protection.

During most of the 70s, the essence of the wage bargaining system consisted of setting the nominal wage, in period $t$, as a mark-up over the prices in period $t-1$. This mechanism guaranteed the real wage, on one hand, and allowed the possibility of a wage-price spiral in inflationary periods, on the other. This was the case in the 70s when Spain witnessed a wage-price spiral that drove the inflation rate over $20 \%$ in 1977 . Together with an insourmountable growing foreign deficit, this led to a nation-wide set of agreements between unions and employer's organisations (both were legalised in that year), the government and all political parties in order to overcome the economic turmoil. These were called the Moncloa Pacts and set the policy framework during the early years of the Spanish democracy.

The Moncloa pacts led to a new period of incomes policies according to which unions would reduce their wage claims, so as to avoid massive employment losses and to control inflation; the government would focus on controlling the rise in prices (through a change in the orientation and implementation of the monetary policy, among other things), so as to provide stability and prevent a deterioration of the real wage; and firms, in benefiting from lower wage claims and inflation control (and other economic measures in their support), would avoid massive bankrupcies and be able to face the adjustment. This was combined 
with a new wage-setting mechanism since 1977 of fixing the nominal wage as a mark-up over expected current prices. These incomes policies were implemented over the 1977 to 1986 period through a succession of tripartite agreements (between unions, firms and the government), and effectively put an end to the wage-price spiral. In the mid $80 \mathrm{~s}$ the inflation rate was already below $10 \%$, while the unemployment rate had reached an historical maximum.

The modern system of employment legislation was set up in 1980 when the Worker's Statute was passed. Prior to 1980, the Spanish labour market was paternalistic and highly regulated. The regulations established by the Worker's Statute set the permanent contract as the standard one, and left the temporary contract for specific cases, such as building construction and tourism activities, training periods, temporary replacements of permanent workers or pick-demand needs. The five labour market reforms shown in Table 1 (1984, 1994, 1997, 2001 and 2006) are reforms of the Worker's Statute.

The 1984 reform is probably the most overwhelming one. The unemployment rate had been growing intensively for years, Spain was about to enter the European Economic Community (EEC) and, generally, there was a call for enhancing the flexibility of the labour market. This was done by extending the use of temporary contracts to all situations regardless of their justification. As a result, the share of temporary employment was growing until the early 90 s and then stabilised at about a third of total dependent employment. This is one of the salient features of the Spanish labour market, since this share is twice the EU average it (see Dolado, García-Serrano and Jimeno, 2002).

The reforms undertaken in 1994, 1997, 2001 and 2006 are often regarded as 'counterreforms', since their target was to decrease the excessive use of temporary work. The 1994 reform introduced restrictions in the use of temporary contracts; the 1997 one launched a new highly subsidised permanent contract; the 2001 extended and enhanced the 1997 reform; and the 2006 one gave more incentives to grant permanent contracts to hard-toplace workers, and introduced new measures against the abuse of temporary contracts. Güell and Petrongolo (2007, Table A) provide a useful summary of the legislation on the temporary contracts in Spain since 1980.

The unemployment protection legislation lies in the jurisdiction the public employment agency, which is the Employment National Institute known as the INEM (Instituto Nacional de Empleo). It was created in 1978 with the aim to manage: (i) the public employment service, with a monopolistic situation until the second labour market reform in 1994 allowed private temporary work agencies; (ii) the unemployment benefits (UB) system; and (iii) the training system for the unemployed. It is financed by the social security contributions of employers and employees, and also by the government (that is, from general taxes). 
The UB system is one of the most prominent labour-market institutions in the mainstream literature. The modern UB system in Spain dates from 1980 when contributory and assistance schemes were established. In the contributory scheme the minimum amount of benefits is the national minimum wage (Salario Mínimo Interprofesional, SMI), while the assistance scheme amounts to $75 \%$ of the SMI and targets non-eligible unemployed with family responsibilities. This system was reformed in 1984, 1992 and 2002.

The first UB reform, in 1984, changed the composition of the unemployed and left several social groups without any sort of protection. This was essentially due to the sharp reduction in the coverage rate over the 1980-83 period (from about $65 \%$ of the unemployed to less than $40 \%$ ) together with the huge increase in unemployment (see García de Blas, 1985). In particular, casual workers, young workers and the long-term unemployed. This reform was expansionary. It extended the duration of benefits under the contributory scheme by a third, and doubled the allowances under the assistance scheme, which was also extended to protect new groups (for example causal workers not having completed the minimum contribution period for the contributory scheme).

The 1992 and 2002 reforms were at the opposite end. In 1992, the minimum requirements for entitlement to benefits were made harder, the replacement rate in the first year of benefit was reduced by 10 percentage points, and the maximum duration shortened. The 2002 reform aimed at modernising the public employment service. In particular, the aim was to achieve more efficiency in the placement of jobseekers and to prevent existing failures within the unemployment insurance system. It also aimed at encouraging the reinsertion of jobseekers, and at extending the unemployment insurance to those particularly disadvantaged. The main novelty was the need, for all beneficiaries, to sign a 'jobseeker agreement': the worker must prove s/he is actively searching for a job and willing to accept a suitable offer, if not, the unemployment benefit may be interrupted.

\subsection{The Integration Process}

Spain entered the EEC in 1986. The reduction in all tariff barriers was the first requirement in order to become a full member of the EEC as a free trade area (see Polo and Sancho, 1993). In the light of the historical levels of high protection, a transitory period was arranged until the end of 1992, i.e. the year scheduled for the creation of a single market for EEC members. In addition to the free movements of goods and services (free trade area), the common market envisaged free movements of labour and capital. In contrast to the several decades that the countries which originally signed the Rome Treaty in 1957 had to adjust, Spain had 6 years to prepare for the common market. This resulted in one of the most intensive periods of economic changes, in particular with respect to trade, the balance of trade, openness, and the composition of output. The rapid increase 
in the trade deficit was one of the striking features of this period.

In the second half of the 80s and early 90s Spain had, on the trading side, to (i) eliminate both tariff and non-tariff trading barriers for EEC members, (ii) adopt the external common tariff system, and (iii) suppress all sort of export subsidies. On the fiscal side, the requirement was the implementation of an indirect tax reform to convert the old cascade turnover tax system into the current value added tax system. On the financial side, Spain had to liberalise the financial sector and free capital movements. This was important, since the historical strict regulation of financial activities in Spain had been blocking the entry of foreign banks for a long time and caused high interest rates.

Indeed, financial liberalisation led to an inflow of foreign capital and a fall in the cost of capital. However, like the rest of Europe, the sharp decline in real interest rates was propagated by the fall in the German interest rate in 1995, when the inflation brought by the unification process was under control and the pressure to meet the Maastricht criterion on interest rates became increasing. The traditional monopolistic power of the incumbent banks in Spain ensured that, even after the financial liberalisation of the 90s, they maintained strong positions in the major industrial firms, and blocked a significant presence of foreign banks in Spain.

In June 1989, Spain joined the European Monetary System (EMS) and adopted the European Exchange Rate Mechanism, according to which the exchange rates of the member's currencies were quasi-fixed and could only fluctuate within some margins - a narrow margin of $\pm 2.25 \%$ and a wider one of $\pm 6 \%$. The latter had to be increased to $\pm 15 \%$ after the 1992/1993 EMS crisis to accommodate persistent speculation on some currencies, the peseta among them. The strong trade deficit put downward pressure on the peseta, which was overcame by the massive inflow of foreign capital. The strong value of the peseta in the late 80 s and early 90 s was thus dependent on capital movements, which in the early 90 s were mainly driven by currency speculators. This speculation prompted the EMS crisis of 1992/1993 (see Eichengreen, 2000), which forced the peseta to loose more than $20 \%$ of its value through successive depreciations $(5 \%$ and $6 \%$ in September and November 1992; $8 \%$ in 1993, and 7\% in 1995). Spain entered the EMS system with an exchange rate of 65 pesetas per Deutsche Mark, but pegged it at 85.1 in 1998 in view of joining the euro in January 1999. This, as expected, progressively reduced the trade deficit in the following years, until it reached a balance in 1998.

Discussions on the future European Monetary Union (EMU) across the EEC members had already begun in the late 80s and early 90s, posing new challenges for the Spanish economy. In particular, the signing of the Maastricht Treaty in 1992 dominated economic policy until 1999, while the independence of the Bank of Spain took place in 1994 in 
anticipation of the European Central Bank (ECB). In 1999 Spain joined the EMU, thus entering what currently is the final stage of the European integration process. The fiscal policy is still in national hands, but subject to the stability and growth pact that restricts public deficits and debts.

Last but not least, Spain has been the recipient of a substantial amount of structural and cohesion aid funding through various European programmes, since it first joined the EEC. The impact of such funds is estimated to be, on average, close to 0.4 percentage points of annual GDP growth over the recent decades (Sosvilla-Rivero and Herce, 2008).

Note that our empirical model in Section 4 evaluates the influence of the above integration process on the evolution of unemployment by including the trade deficit (foreign demand), indirect taxes, financial wealth, and capital accumulation in the set of explanatory variables.

\subsection{The Rise and Fall of Unemployment across Business Cycles}

\subsection{1 $\quad 1977-1985$}

Following the enduring expansion of the $60 \mathrm{~s}$ and early $70 \mathrm{~s}$, Spain had to deal with two severe world macroeconomic shocks. The first oil price shock in 1973 had a pronounced effect on inflation and unemployment since the Spanish industry was heavily dependent on oil imports. This was further coupled by a wage-price spiral over the 1973-77 period, in which unions pushed wages sufficiently up to generate real wage growth.

The wage-price spiral was aggravated by accommodating macroeconomic policies. This policy response, in the context of the social and political crises linked with the end of the Francoist period in 1975 and the first democratic elections in 1977, effectively postponed the adjustment to the economic turmoil. As a result, inflation exceeded $20 \%$ in 1977 , while the unemployment rate remained close to full employment levels until 1977 (in that year it was still $4.2 \%$ ).

The deep economic crisis was fully felt from 1977 to 1985 with a rapid increase in the unemployment rate, which reached $17.8 \%$ in $1985 .{ }^{14}$ The second oil price shock in 1979 exacerbated this crisis. A very restrictive monetary policy was implemented during this period to reduce inflation. As a consequence investment and consumption fell dramatically, while the interest rates and unemployment rose sharply (the unemployment rate went up by 13.6 percentage points during these years). The profound downturn in the growth rate of capital stock (Figure 8 in Section 4) is representative of the slump during these years.

In contrast, the fiscal policy was very expansionary, with public expenditures growing

\footnotetext{
${ }^{14}$ Recall that we use the OECD Economic Outlook series (rather than the EPA ones).
} 
much faster than public revenues, and the public deficit reaching around $7 \%$ of GDP. The rise in public expenditures is both conjunctural (due to the crisis) and structural (due to the administrative decentralisation and the setting up of a modern welfare state).

Regarding the external sector, the peseta was devalued against the US dollar: $20 \%$ in 1977 in the context of the Moncloa Pacts, and 7.6\% in 1982.

Furthermore, as already explained, the Moncloa Pacts led to the implementation of an incomes policy, whereby the government set an inflation target, the unions agreed to accept moderation in wage increases, and firms agreed to price moderation. Despite the various annual and biannual agreements signed until the mid 80s, job destruction was significant throughout this period. In 1984, the government introduced a series of labour market reforms, the details of which were discussed in the previous section.

- In a nutshell, over the 1977-1985 period, whereas inflation and external deficit were brought under control, unemployment and public deficit remained the two main macroeconomic imbalances until 1985.

\subsubsection{6-1990}

Strong expansion is the charateristic of this period. GDP grew at a $4.5 \%$ annual rate, fueled by strong domestic demand. The unemployment rate went down from $17.7 \%$ in 1985 to $12.1 \%$ in 1990.

Spain joined the EEC in 1986 after being a closed economy with highly protected product markets. Thus, foreign deficit increased at a rapid pace and the need for international competitiveness put downward pressure on wages and prices (even in the absence of new incomes policies).

Monetary policy was relaxed in 1986 and 1987 (given the subdued inflation rates), while the fiscal policy became restrictive. The expansion was based on the boost in domestic demand and was led by the increase in private consumption and investment. These developments, together with the lagged effects of the labour market reforms of 1984, led to a sharp increase in employment ${ }^{15}$. In 1988-90 these policies was reversed, especially after Spain joined the EMS in 1989. To prevent a resurgence of high inflation, monetary policies were tightened in the late $80 \mathrm{~s}$, a move reinforced by the EMS entry. In 1989 the monetary policy became anchored to the foreign sector, aiming at controlling inflation and the value of the peseta, until the ECB would take over in 1999.

\subsubsection{1-1994}

The "EU cycle" boom of 1986-1990 was followed by the "EU cycle" recession of 1991-1994.

\footnotetext{
${ }^{15}$ Whereas temporary contracts were infrequent prior to 1984 , the ratio of fixed-tem employment to dependent employment rose to $15.6 \%$ in 1987 (first year with official data), and further to $32.2 \%$ in 1991 .
} 
Job creation started slowing down and the unemployment rate stopped falling in 1991 as domestic demand collapsed: first private investment, then private consumption. A rise in household indebtedness, the Iraqi war of 1991, the upward pressure on interest rates due to German unification, and the EMS crisis of 1992 and 1993 together pushed the Spanish economy into a short-lived but deep recession. The unemployment rate rose from $12.1 \%$ in 1990 to $19.1 \%$ in 1994 . This recession was accompanied by a decline in the inflation rates, from around 7\% in 1990 to less than $4.0 \%$ in 1994.

From 1990 the value of the peseta became less credible. On one side, the current account deficit put downward pressure on it. On the other side, high interest rates were attracting short-run foreign capital which increased the demand of pesetas. When Germany raised its interest rates to control the inflation generated by the unification process, this foreign capital flew out to Germany leaving the peseta value unsustainable and subject to strong speculative attacks. The successive devaluations of the peseta following the EMS crisis made Spanish exports more competitive.

\subsubsection{5-2005}

This was a prolonged expansionary period with GDP growing around $3.5 \%$ on average. ${ }^{16}$ In 1994 the Spanish government implemented a second wave of labour market reforms ${ }^{17}$, and the Central Bank became independent, with a mandate to focus exclusively on inflation control. 1997 witnessed a third wave of reforms, which reduced firing costs on permanent contracts thereby partially reversing the trend towards temporary employment.

These two labour market reforms played an important role in containing real wage growth and, along with a new cyclical upturn, provided a strong stimulus to employment in the second half of the nineties. The peseta devaluation of approximately $20 \%$ with respect to the Deutsche Mark in 1992 and 1993 contributed to balance the foreign deficit until 1998, when the exhange rates of the EMU countries were fixed. These developments were reinforced by the monetary policy run-up to Spain's EMU entry in 1999, involving a sharp reduction in interest rates after 1995. Nevertheless, in order to keep inflation under control, the government supplemented its labour market reforms by opening its product

\footnotetext{
${ }^{16}$ In fact, this expansion lasts until 2007. However, data availability at the time this research was conducted restricts the sample period to 2005 .

${ }^{17}$ This second wave was a response to the first. The main fixed-term contract in the 1984 reform was the 'employment promotion contract,' which was used heavily by employers to cover both temporary and permanent tasks, and it gave Spain the highest rate of temporary employment in the EU. Thus, in the second wave of labour market reform of 1994, the government tried to restrict the use of this contract by substituting it for other temporary contracts, such as the 'contract per task or service' and the 'contract for launching new activities'. These were originally targeted towards some groups of hardto-place workers, but in fact they were used in the same way as the previous contract. As result, the third wave of reform in 1997 was implemented to favour permanent contracts.
} 
markets to foreign competition. Whereas this involved mainly the industrial sector in the second half of the 80s, in the 90s it included the service sector, particularly the financial, transport, communication and telecommunication sectors. Several important public companies were privatised, which helped reduce the public sector deficit. As a result, the pronounced increase in employment in the second half of the 90s was accompanied by a reduction in inflation. However, the labour force expanded (through higher female participation rates) and thus Spain's unemployment rate responded only moderately; in 1998 it was still $14.6 \%$.

The government implemented two fiscal reforms in 1999 and 2003 affecting the income tax. The modern income tax system was established with the Moncloa Pacts in 1978 and went through relatively minor changes until 1999. The 1999 reform of the personal income tax reduced the number of tax-brackets from 8 to 6 , which were further reduced to 5 by the 2003 reform. Moreover, the highest marginal rate fell from 56\% before 1999 to $45 \%$ after 2003, and the lowest marginal rate fell from $20 \%$ to $15 \%$. These changes entailed a reduction in the average tax rate so that, jointly, these reforms increased net real wages by the equivalent of about $1 \%$ of GDP according to official figures. In the context of low interest rates, the increase in real wages is one of the main factors behind the strong increase in private consumption until 2007. This, in turn, fed through to the continuous and rapid GDP growth, kept investment high and, thereby, boosted employment.

The immigration boom experienced by the Spanish economy in the early 2000s is another main factor behind the increase in private consumption. In 2000 the Spanish population was 40.5 million people with a tiny share of migrants. In 2006 it had grown to 44.7 million and the proportion of foreigners was above $10 \%$. This rapid population increase boosted private consumption and reinforced building construction, the two characteristic features of the Spanish economy until 2007.

The increase in the labour force resulting from the massive waves of immigrants has also implied a reduction in the speed at which the unemployment rate had been falling in previous years. It went down from $14.6 \%$ in 1998 to $10.8 \%$ in 2000 , and to $8.5 \%$ in 2006 (after some stabilisation in 2002-2003).

\section{Empirical Analysis}

In the spirit of the chain reaction theory model in Section 2 and the economic developments discussed above, we identify the driving forces of the unemployment rate by estimating a dynamic structural multi-equation labour market model containing labour demand, 
labour supply and wage setting equations:

$$
\underset{(3 \times 3)(3 \times 1)}{\mathbf{A}_{0}} \underset{\mathbf{y}_{t}}{\mathbf{y}_{t}}=\sum_{i=1}^{2} \underset{(3 \times 3)(3 \times 1)}{\mathbf{A}_{i}} \mathbf{y}_{t-i}+\sum_{i=0}^{2} \underset{(3 \times 8)(8 \times 1)}{\mathbf{D}_{i} \mathbf{x}_{t-i}}+\underset{(3 \times 1)}{\boldsymbol{\varepsilon}_{t}},
$$

where $\mathbf{y}_{t}$ is a $(3 \times 1)$ vector of endogenous variables, $\mathbf{x}_{t}$ is an $(8 \times 1)$ vector of exogenous variables, the $\mathbf{A}_{i}$ 's and $\mathbf{D}_{i}$ 's are $(3 \times 3)$ and $(3 \times 8)$, respectively, coefficient matrices, and $\mathbf{e}_{t}$ is a $(3 \times 1)$ vector of strict white noise error terms.

The above dynamic system is stable when all the roots of the determinantal equation: $\left|\mathbf{A}_{0}-\mathbf{A}_{1} B-\mathbf{A}_{2} B^{2}\right|=0$ lie outside the unit circle.

\subsection{Econometric Methodology}

We apply the autoregressive distributed lag (ARDL) approach, which was developed by Pesaran and Shin (1999), and Pesaran, Shin and Smith (2001). The ARDL is an alternative to the popular cointegration/error-correction methodology, having the advantage of avoiding the pretesting problem implicit in the standard cointegration techniques (i.e. the Johansen maximum likelihood, and the Phillips-Hansen semi-parametric fully-modified OLS procedures).

It can be shown that the ARDL yields consistent short- and long-run estimates irrespective of whether the regressors are $\mathrm{I}(1)$ or $\mathrm{I}(0)$. Thus, the ARDL provides us with an econometric tool to conduct our empirical analysis rigorously. To determine the dynamic specification of each equation we rely on the optimal lag-length algorithm of the Schwartz information criterion.

It is important to note that the equations we select are dynamically stable and pass the standard diagnostic tests at conventional significance levels, i.e. they satisfy the conditions of linearity, structural stability, no serial correlation, homoskedasticity, and normality.

To take into account the potential endogeneity and cross equation correlation, we estimate our equations as a system using 3SLS. These estimated equations, together with the unemployment definition (4), are then used to derive the univariate representation of the unemployment rate underlying the rest of our empirical analysis.

In what follows, we present our estimation results and then provide an overall evaluation of the empirical labour market model.

\subsection{Data and Estimated Equations}

Our sample covers the 1972-2005 period and the data is obtained by the [1] OECD Economic Outlook, [2] FBBVA, [3] Madrid Stock Exchange, and [4] Bank of Spain. The 
variables are defined in Table $2 .^{18}$

\section{Table 2: Definitions of variables.}

\begin{tabular}{|c|c|c|c|c|c|}
\hline & & Source: & & & Source: \\
\hline$c$ & constant & & & & \\
\hline$n$ & employment (log) & {$[1]$} & $i g b m$ & Madrid stock exchange index & {$[3]$} \\
\hline$l$ & labour force (log) & {$[1]$} & $P$ & GDP deflator & {$[1]$} \\
\hline$u$ & unemployment rate, $l-n$ & {$[1]$} & $f w$ & financial wealth, $\log \left(\frac{i g m p / P}{\theta}\right)$ & \\
\hline$k$ & real capital stock $(\log )$ & {$[2]$} & $b$ & social security benefits (\% GDP) & {$[1]$} \\
\hline$w$ & real wage per employee (log) & {$[1]$} & $f d$ & foreign demand, $\left(\frac{\text { exports - imports }}{\text { GDP }}\right)$ & {$[1]$} \\
\hline$\tau a x^{i}$ & Indirect taxes (\% GDP) & {$[3]$} & $z$ & working-age population (log) & {$[1]$} \\
\hline cons & private consumption (\% GDP) & {$[1]$} & $z p$ & $\frac{\text { working-age population }}{\text { total population }}$ & {$[4]$} \\
\hline$\theta$ & real labour productivity & {$[1]$} & $d^{00}$ & $\begin{array}{r}\text { dummy, value }=1,2000-05 \\
0, \text { otherwise }\end{array}$ & \\
\hline
\end{tabular}

In Tables 3-5 we present the estimates for the labour demand, wage setting and labour force equations, respectively. The first part of each table gives the least squares estimates of the specific equation, while its misspecification tests are shown in the second part of the table. The 3SLS estimates are given in the third part of each table. It is important to note that all three equations are dynamically stable. ${ }^{19}$ Finally, according to the reported pvalues, all parameters are statistically significant and all three equations are well specified at conventional significance levels. ${ }^{20}$

\subsubsection{Labour Demand}

The labour demand equation is quite standard (see Table 3). Employment depends positively on capital stock, ${ }^{21}$ and negatively on real wages and indirect taxes. The performance of the stock market enters the labour demand equation with a small coefficient and the expected positive sign. ${ }^{22}$ Other product demand-side influences are captured through foreign demand and private consumption, both having the expected positive sign. Finally, observe that the sum of the lagged dependent variable coefficients is 0.66 , implying a

\footnotetext{
${ }^{18}$ Our wider set of explanatory variables also included direct taxes, oil prices, and social security contributions, but they were not significant.

${ }^{19}$ If we measure persistence by the sum of the autoregressive coefficients, then wage-setting has the lowest persistence (0.44), followed by labour demand (0.66) and labour supply (0.86).

${ }^{20}$ For example, for the wage-setting equation, linearity cannot be rejected at significance levels of (at most) $2 \%$ with a chi-square test, or $4.4 \%$ with an F-test.

${ }^{21}$ The restriction that the elasticity of substitution is unity cannot be rejected. We believe that this restriction has no bearing on our work. If, however, it is interpretted as indicative of an underlying Cobb-Douglas production function, it can only reinforce our results regarding the importance of capital accumulation for the evolution of unemployment (see the next section).

${ }^{22}$ This is along the lines of Phelps (1999), who was the first to draw attention to the role played by financial wealth in the (US) labour market.
} 
rather high degree of employment persistence.

\begin{tabular}{|c|c|c|c|c|c|c|c|}
\hline \multicolumn{3}{|c|}{ OLS } & \multicolumn{2}{|c|}{ Misspecification tests } & \multicolumn{3}{|c|}{$3 \mathrm{SLS}$} \\
\hline & Coeff. & [p-value] & \multirow{2}{*}{\multicolumn{2}{|c|}{ [p-value] }} & \multirow[b]{2}{*}{$c$} & Coeff. & {$[\mathrm{p}$-value $]$} \\
\hline$c$ & 1.79 & {$[0.070]$} & & & & 2.23 & {$[0.000]$} \\
\hline$n_{t-1}$ & 0.69 & {$[0.000]$} & $\mathrm{SC}\left[\chi^{2}(1)\right]$ & $1.07[0.301]$ & $n_{t-1}$ & 0.66 & {$[0.000]$} \\
\hline$\Delta n_{t-1}$ & 0.34 & [0.001] & $\operatorname{LIN}\left[\chi^{2}(1)\right]$ & $2.51[0.113]$ & $\Delta n_{t-1}$ & 0.36 & {$[0.000]$} \\
\hline$w_{t}$ & -0.31 & {$[0.004]$} & $\operatorname{NOR}\left[\chi^{2}(2)\right]$ & $0.42[0.812]$ & $w_{t}$ & -0.37 & {$[0.000]$} \\
\hline $\operatorname{tax}_{t}^{i}$ & -0.85 & {$[0.017]$} & $\operatorname{HET}\left[\chi^{2}(1)\right]$ & $1.75[0.812]$ & $\operatorname{tax}_{t}^{i}$ & -0.96 & {$[0.000]$} \\
\hline$k_{t}$ & 0.32 & {$[0.000]$} & $\operatorname{ARCH}\left[\chi^{2}(1)\right]$ & $0.51[0.476]$ & $k_{t}$ & 0.34 & $*$ \\
\hline$\Delta k_{t}$ & 2.77 & {$[0.001]$} & & & $\Delta k_{t}$ & 2.68 & {$[0.000]$} \\
\hline$\Delta k_{t-1}$ & -1.22 & {$[0.073]$} & Structural st & bility tests & $\Delta k_{t-1}$ & -1.20 & {$[0.014]$} \\
\hline$f w_{t-1}$ & 0.01 & {$[0.029]$} & (5\% signi & cance) & $f w_{t}$ & 0.01 & {$[0.000]$} \\
\hline$\Delta f w_{t-1}$ & -0.02 & {$[0.033]$} & & & $\Delta f w_{t}$ & -0.01 & {$[0.001]$} \\
\hline$f d_{t-1}$ & 0.48 & {$[0.009]$} & CUSUM & $\checkmark$ & $f d_{t-1}$ & 0.40 & {$[0.000]$} \\
\hline $\mathrm{cons}_{t}$ & 0.64 & [0.033] & CUSUM $^{2}$ & $\checkmark$ & consst $_{t}$ & 0.65 & {$[0.003]$} \\
\hline & error & 0.007 & & & & error & 0.007 \\
\hline & $R^{2}$ & 0.998 & & & $(*)$ & $R^{2}$ & 0.998 \\
\hline
\end{tabular}

\subsubsection{Wage Setting}

Real wage depends on its lagged values, the unemployment rate, capital deepening, social security benefits, and indirect taxes (see Table 4). Capital deepening is regarded as a good proxy for labour productivity. The advantage of using capital deepening instead of productivity is that we avoid dealing with an additional endogenous variable in our estimation.

In line with the classical assumption, unemployment puts downward pressure on real wages, with a semi-elasticity of 0.23 in the short-run. In addition, if the unemployment rate goes up by 1 percentage point, wages fall by $0.41 \%$ in the long-run. The effect of capital deepening on wages is captured by a long-run coefficient of 0.52 . The significant positive effect of benefits flags their role as the conventional wage-push factor. Finally, although the wage equation depends negatively on taxes, their "global" effect on unemployment has the expected positive sign. ${ }^{23}$ In fact, the "global" long-run slope of the

\footnotetext{
${ }^{23}$ See Section 2 for the distinction between "local" and "global" sensitivities.
} 
unemployment rate with respect to the tax rate is $1.36 .^{24}$

\begin{tabular}{|c|c|c|c|c|c|c|c|}
\hline \multicolumn{3}{|c|}{ OLS } & \multicolumn{2}{|c|}{ Misspecification tests } & \multicolumn{3}{|c|}{ 3SLS } \\
\hline & Coeff. & [p-value] & & [p-value] & & Coeff. & [p-value] \\
\hline$c$ & 3.46 & {$[0.008]$} & $\mathrm{SC}\left[\chi^{2}(1)\right]$ & $0.10[0.752]$ & $c$ & 3.57 & {$[0.001]$} \\
\hline$w_{t-1}$ & 0.46 & {$[0.010]$} & $\operatorname{LIN}\left[\chi^{2}(1)\right]$ & $5.37[0.020]$ & $w_{t-1}$ & 0.44 & {$[0.003]$} \\
\hline$\Delta w_{t-1}$ & 0.48 & {$[0.004]$} & $\operatorname{LIN}[\digamma(1,24)]$ & $4.50[0.044]$ & $\Delta w_{t-1}$ & 0.46 & {$[0.001]$} \\
\hline$u_{t}$ & -0.23 & {$[0.021]$} & $\operatorname{NOR}\left[\chi^{2}(2)\right]$ & $0.20[0.904]$ & $u_{t}$ & -0.23 & {$[0.005]$} \\
\hline$\Delta u_{t}$ & -0.33 & {$[0.077]$} & $\operatorname{HET}\left[\chi^{2}(1)\right]$ & $0.04[0.849]$ & $\Delta u_{t}$ & -0.32 & {$[0.047]$} \\
\hline$k_{t}-n_{t}$ & 0.28 & {$[0.045]$} & $\operatorname{ARCH}\left[\chi^{2}(1)\right]$ & $0.55[0.460]$ & $k_{t}-n_{t}$ & 0.29 & {$[0.013]$} \\
\hline $\operatorname{tax}_{t}^{i}$ & -1.00 & {$[0.056]$} & \multirow{3}{*}{\multicolumn{2}{|c|}{$\begin{array}{l}\text { Structural stability tests } \\
\text { (5\% significance) }\end{array}$}} & $\operatorname{tax}_{t}^{i}$ & -1.01 & {$[0.021]$} \\
\hline$\Delta \operatorname{tax}_{t}^{i}$ & -0.85 & {$[0.087]$} & & & $\Delta \operatorname{tax}_{t}^{i}$ & -1.00 & {$[0.015]$} \\
\hline$b_{t}$ & 0.78 & {$[0.067]$} & & & $b_{t}$ & 0.78 & {$[0.030]$} \\
\hline sta & error & 0.011 & CUSUM & $\checkmark$ & & error & 0.011 \\
\hline & $R^{2}$ & 0.995 & CUSUM $^{2}$ & $\checkmark$ & & $R^{2}$ & 0.995 \\
\hline
\end{tabular}

\subsubsection{Labour Supply}

In contrast to wage setting, inertia in labour supply decisions is large, with a persistence coefficient of 0.86. Labour supply is driven by the unemployment rate, real wage, and working-age population (see Table 5).

Since it is the change rather than the level of unemployment that enters the labour force equation, we have the so called discouraged workers' effect influencing labour supply. Labour force depends negatively on the real wage, which indicates that the income effect dominates. ${ }^{25}$ Both the level of working-age population $(z)$ and its ratio to total population $(z p)$ affect positively the labour force. Note that through $z p$ we can capture demographic influences on the labour supply movements. Finally, the dummy variable $\left(d^{00}\right)$ captures the influence of the immigration boom since 2000 .

\footnotetext{
${ }^{24}$ If we consider that, on average in our sample, the size of a tax change is 0.02 , then the effect of taxes on unemployment is $1.36 \times 0.02=0.027$. That is, the overall impact of a tax shock on unemployment is an increase of 0.027 percentage points.

${ }^{25}$ This result is also obtained by Bande and Karanassou (2008) using Spanish regional data from 1980 to 1995.
} 


\begin{tabular}{|c|c|c|c|c|c|c|c|}
\hline \multicolumn{3}{|c|}{ OLS } & \multicolumn{2}{|c|}{ Misspecification tests } & \multicolumn{3}{|c|}{ 3SLS } \\
\hline & Coeff. & [p-value] & \multirow{2}{*}{\multicolumn{2}{|c|}{ [p-value] }} & \multicolumn{2}{|c|}{ Coeff. } & [p-value] \\
\hline$c$ & -0.69 & {$[0.551]$} & & & $c$ & -0.07 & {$[0.175]$} \\
\hline$l_{t-1}$ & 0.85 & {$[0.000]$} & $\mathrm{SC}\left[\chi^{2}(1)\right]$ & $0.25[0.616]$ & $l_{t-1}$ & 0.86 & {$[0.000]$} \\
\hline$w_{t}$ & -0.06 & {$[0.144]$} & $\operatorname{LIN}\left[\chi^{2}(1)\right]$ & $0.40[0.529]$ & $w_{t}$ & -0.06 & {$[0.045]$} \\
\hline$\Delta u_{t}$ & -0.21 & {$[0.048]$} & $\operatorname{NOR}\left[\chi^{2}(2)\right]$ & $2.91[0.234]$ & $\Delta u_{t}$ & -0.20 & {$[0.011]$} \\
\hline$z_{t}$ & 0.19 & {$[0.120]$} & $\operatorname{HET}\left[\chi^{2}(1)\right]$ & $0.32[0.570]$ & $z_{t}$ & 0.14 & $(*)$ \\
\hline$z p_{t}$ & 0.32 & {$[0.154]$} & $\operatorname{ARCH}\left[\chi^{2}(1)\right]$ & $0.46[0.495]$ & $z p_{t}$ & 0.46 & {$[0.003]$} \\
\hline$\Delta z p_{t}$ & -2.30 & {$[0.195]$} & \multirow{2}{*}{\multicolumn{2}{|c|}{$\begin{array}{l}\text { Structural stability tests } \\
\quad(5 \% \text { significance })\end{array}$}} & $\Delta z p_{t}$ & -2.03 & {$[0.083]$} \\
\hline$d^{00}$ & 0.02 & {$[0.002]$} & & & $d^{00}$ & 0.03 & {$[0.000]$} \\
\hline \multirow{3}{*}{\multicolumn{2}{|c|}{$\begin{array}{r}\text { std. error } \\
R^{2}\end{array}$}} & \multirow{3}{*}{$\begin{array}{l}0.006 \\
0.998\end{array}$} & \multirow{3}{*}{\multicolumn{2}{|c|}{$\begin{array}{r}\text { CUSUM } \\
\text { CUSUM }^{2}\end{array}$}} & \multicolumn{2}{|c|}{ std. error } & 0.007 \\
\hline & & & & & & $R^{2}$ & 0.998 \\
\hline & & & & & \multicolumn{3}{|c|}{ Restricted to unity. } \\
\hline
\end{tabular}

\subsection{Model Diagnostics}

We check the economic plausibility and overall validity of the estimated system by

- looking at the accuracy of the fitted values,

- computing the "global" (interactive) sensitivities, and

- using the Johansen framework to test for the cointegrating vectors implied by the ARDL.

The fitted values of the unemployment rate can be obtained by using the estimated (3SLS) equations in Tables 3-5 and the unemployment definition (4). Figure 3 plots the actual and fitted values of the unemployment rate and shows that our estimation tracks the data very well. We should emphasize that a good fit is much harder to obtain when dynamic multi-equation labour market models are being estimated instead of single unemployment rate equations. This is because of the numerous feedback mechanisms among the endogenous variables that are activated when we solve the model for the unemployment rate. 
Figure 3. Unemployment rate: actual and fitted values

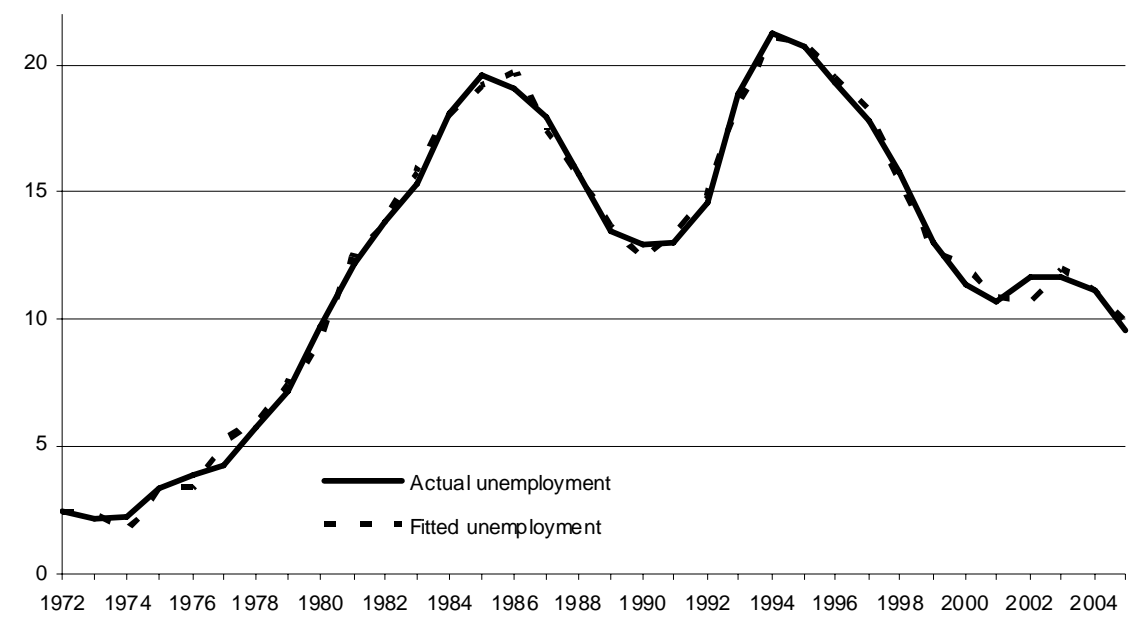

As explained in Section 2.1, the "global" slopes or semi-elasticities of an endogenous variable with respect to the exogenous ones incorporate all the spillover effects in the system, and are thus differentiated by the "local" sensitivities, which are readily displayed by the individual equations. We call them "global" because (in the short-run) they are the slopes/semi-elasticities of the univariate representation of the unemployment rate. As shown in equation (12), the long-run "global" sensitivities can be computed by the infinite sum of responses to an impulse. We also argued in Section 2.3 that the "global" sensitivities are an invaluable tool to decide on the economic plausibility of the empirical model. The disadvantage of the traditional structural labour market models is their focus on the "local" sensitivities whose size and sign can be dramatically affected by the spillovers in the system.

Table 6 presents the "global" long-run sensitivities and the magnitudes of the respective shocks. The latter are measured by the sample average of the change in the specific variable. As expected, taxes, benefits, and working-age population put upward pressure on unemployment, whereas capital stock, foreign demand, the performance of the stock market, and consumption reduce unemployment.

\begin{tabular}{|c|c|c|c|c|c|c|c|c|}
\hline & $\operatorname{tax} x^{i}$ & $b$ & $f w$ & $f d$ & cons & $k$ & $z$ & $z p$ \\
\hline $\begin{array}{l}\text { LR sensitivity } \\
\text { (Shock size) }\end{array}$ & $\begin{array}{c}1.36 \\
(0.02)\end{array}$ & $\begin{array}{c}1.37 \\
(0.02)\end{array}$ & $\begin{array}{l}-0.04 \\
(0.71)\end{array}$ & $\begin{array}{l}-1.31 \\
(0.03)\end{array}$ & $\begin{array}{l}-2.13 \\
(0.02)\end{array}$ & $\begin{array}{l}-0.60 \\
(0.36)\end{array}$ & $\begin{array}{c}0.60 \\
(0.10)\end{array}$ & $\begin{array}{l}1.93 \\
(0.03)\end{array}$ \\
\hline
\end{tabular}

Finally, we test whether the long-run relationships implied by our estimations (second column in Table 7) translate to cointegrating vectors within the Johansen framework. 
Once the maximal eigenvalue and trace statistics confirm that the variables involved in each equation are cointegrated, the Johansen's cointegrating vectors (third column in Table 7) are restricted to take the corresponding long-run values of our estimated equations. The last column in Table 7 displays the LR tests following a $\chi^{2}(\cdot)$ distribution. ${ }^{26}$ Observe that the restrictions cannot be rejected at any conventional size of the test, indicating that our estimation methodology is consistent with the Johansen procedure.

\begin{tabular}{|c|c|c|c|c|c|c|}
\hline \multirow[b]{2}{*}{ Labour demand } & \multicolumn{3}{|c|}{ ARDL } & \multicolumn{2}{|l|}{ Johansen } & \multirow[t]{2}{*}{ LR test } \\
\hline & $(\Lambda$ & $w$ & $k$ & $(N$ & $k$ & \\
\hline OLS & 1 & -1.01 & 1.02 & $1-1.09$ & 1.23 & $\chi^{2}(2)=0.76[0.685]$ \\
\hline 3SLS & 1 & -1.09 & 1.00 & $1-1.09$ & 1.23 & $\chi^{2}(2)=1.26[0.533]$ \\
\hline Wage setting & $u$ & $k$ & $n$ & $w$ & $n$ & \\
\hline OLS & 1 & -0.52 & $0.52)$ & $1-0.61$ & 0.74 & $\chi^{2}(2)=3.12[0.210]$ \\
\hline 3SLS & 1 & -0.52 & $0.52)$ & $1-0.61$ & 0.74 & $\chi^{2}(2)=3.12[0.210]$ \\
\hline Labour force & $L$ & $w$ & $z)^{\prime}$ & $w$ & $z)^{\prime}$ & \\
\hline OLS & 1 & 0.40 & $-1.29)$ & 10.15 & $-0.62)$ & $\chi^{2}(2)=0.66[0.720]$ \\
\hline 3SLS & 1 & $0.38-$ & $-1.00)$ & $1 \quad 0.15$ & $-0.62)$ & $\chi^{2}(2)=0.50[0.781]$ \\
\hline
\end{tabular}

\section{Dynamic Contributions}

We examine the influence of (i) social security benefits, (ii) indirect taxes, (iii) financial wealth, (v) foreign demand, and (iv) capital accumulation on the unemployment trajectory over the periods 1978-1985, 1986-1990, 1991-1994, and 1995-2005 by carrying out counterfactual simulations, and applying the technique presented in Section 2.3.

We evaluate the contributions of each of the above factors by plotting the actual series of unemployment against its simulated series obtained by fixing each specific factor at its value at the start of a specific period. The disparity between the actual and simulated series of unemployment measures the dynamic contribution of the specific factor to unemployment for the specific period. The evolution of social security benefits, indirect

\footnotetext{
${ }^{26}$ It should be noted that the VAR model underlying the Johansen procedure contains all the variables in our labour market model, both the I(0) and I(1) variables. Naturally, the cointegration tests, only consider the I(1) variables in our models: $n_{t}, w_{t}, l_{t}, k_{t}$, and $z_{t}$. This implies that we test two restrictions in the labour demand, wage setting, and labour suply equations. To conserve space, we do not report the results of the underlying unit root and cointegration tests. These are available upon request.

${ }^{27}$ The coefficients are presented up to the second decimal, but the computations take all the information into account. In a couple of cases, this turns into slight differences with respect to the cointegrating vectors derived from the information provided in tables 2,3 and 4 .
} 
taxes, financial wealth, foreign demand, and capital stock growth and their contribution to the rise and fall in unemployment are plotted in Figures 4-8, respectively.

Figure 4 shows that had social security benefits remained constant at its value in

- 1977, the unemployment rate would have been 6.1 percentage points (pp) below the actual 15.4 pp increase over the 1978-1985 recession period,

- 1985, unemployment would have been 0.5 pp above the 6.7 pp decrease over the 1986-1991 boom period, ${ }^{28}$

- 1990, unemployment would have been 2.0 pp below the 8.3 pp increase over the 1991-1994 recession period, and

- 1994, unemployment would have been 3.7 pp above the 11.6 pp decrease over the 1995-2005 boom period.

According to Figure 5, whereas indirect taxes have negligible contributions during the first three periods, they put upward pressure on unemployment during the boom period 1995-2005. Had taxes not increased, the unemployment rate would have ended the period $1.6 \mathrm{pp}$ below the actual $11.6 \mathrm{pp}$ decrease. We should point out that the substantial increase in the indirect tax rate during the long recession of 1978-1985 had virtually no impact on the unemployment rate.

Figure 6 displays the downward pressure of the stock market activity on the unemployment rate. Had financial wealth ${ }^{29}$ remained fixed at its value in

- 1977, unemployment would have been 3.5 pp below the 15.4 pp increase over the 1978-1985 recession,

- 1985, unemployment would have been 2.3 pp above the 6.7 pp decrease over the 1986-1991 boom,

- 1990, unemployment would not have been influenced over the 1991-1994 recession, ${ }^{30}$ and

- 1994, unemployment would have been 2.5 pp above the 11.6 pp decrease over the 1995-2005 boom years.

\footnotetext{
${ }^{28}$ Note that during this period benefits hardly change.

${ }^{29}$ Recall that we use the Phelps normalisation to describe the stock market performance, i.e. the (log of) ratio of(real stock market index to labour market productivity.

${ }^{30}$ This is no surprise as financial wealth is rather stable during these years.
} 
Figure 4. Social security benefits: evolution and unemployment effects

a. Evolution

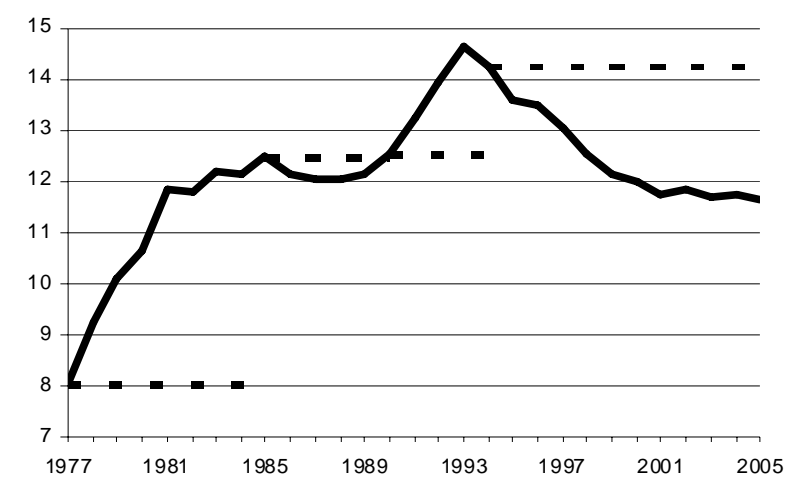

b. $1978-1985$

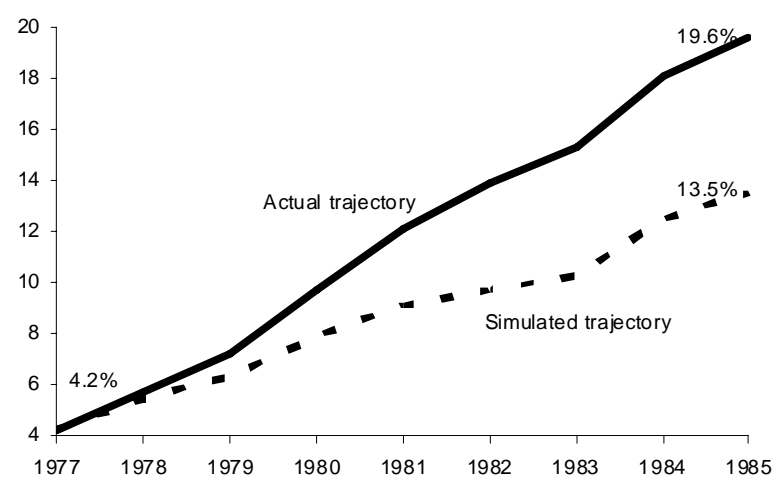

d. $1991-1994$

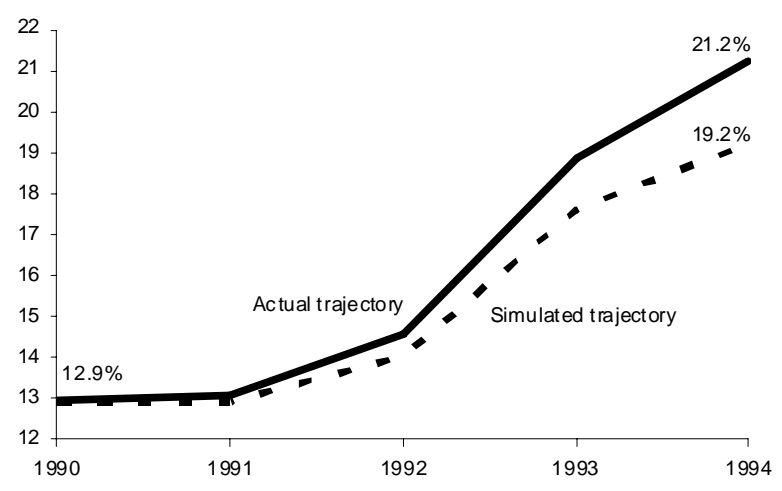

c. $1986-1990$

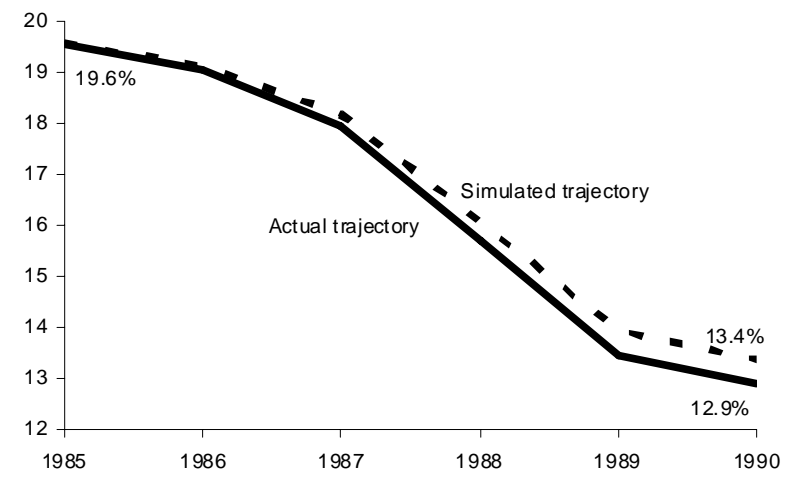

e. $1995-2005$

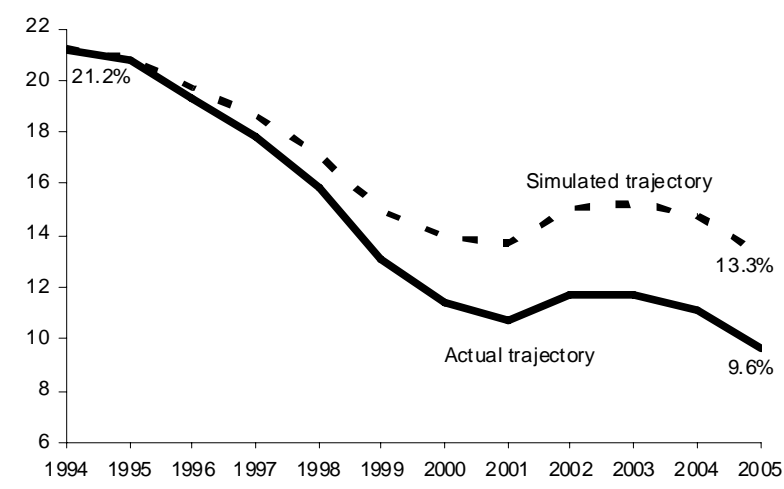
Note: Simulated trajectories result from fixing social security benefits at years 1977, 1985, 1990 and 1994. 
Figure 5. Indirect taxes: evolution and unemployment effects

a. Evolution

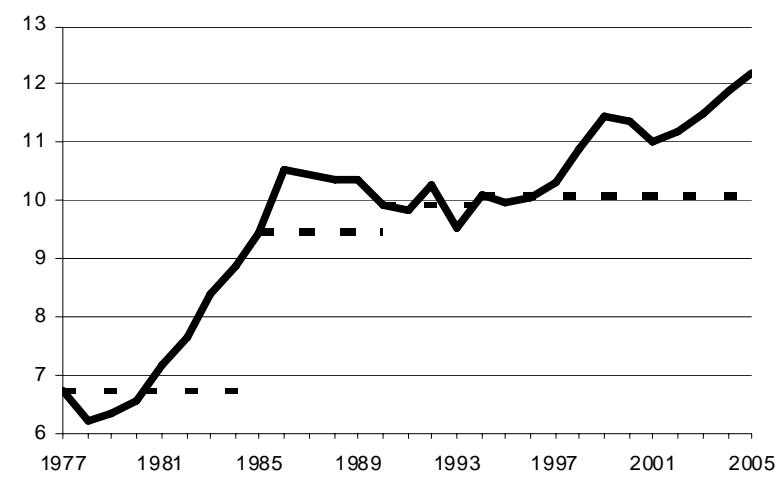

b. $1978-1985$

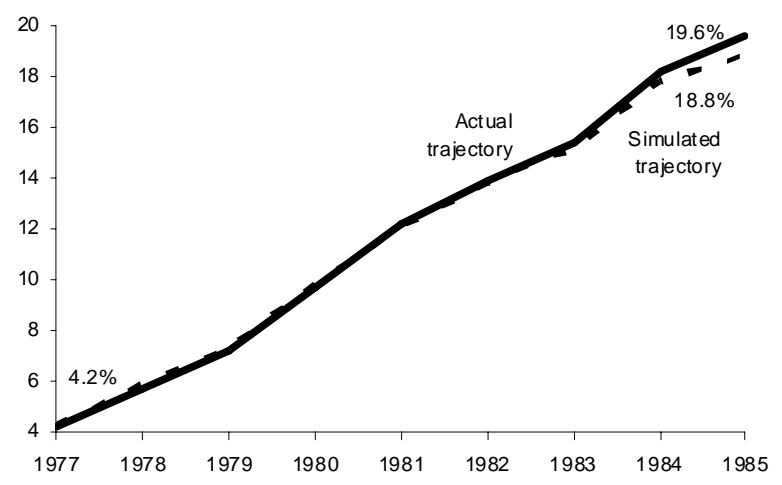

d. $1991-1994$

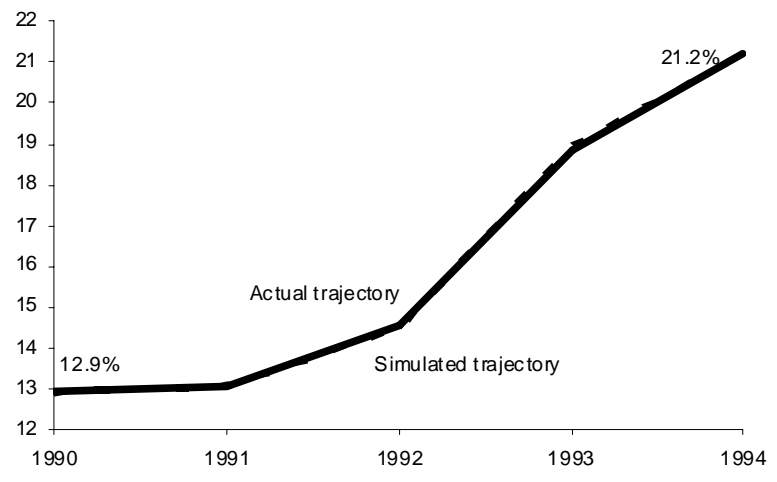

C. $1986-1990$

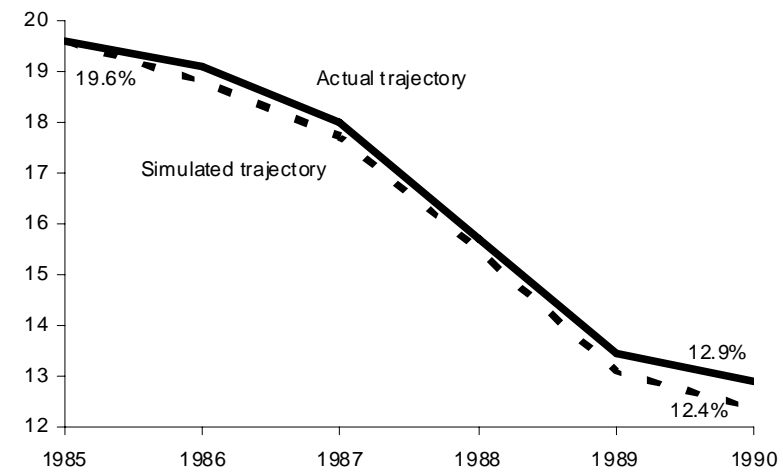

e. $1995-2005$

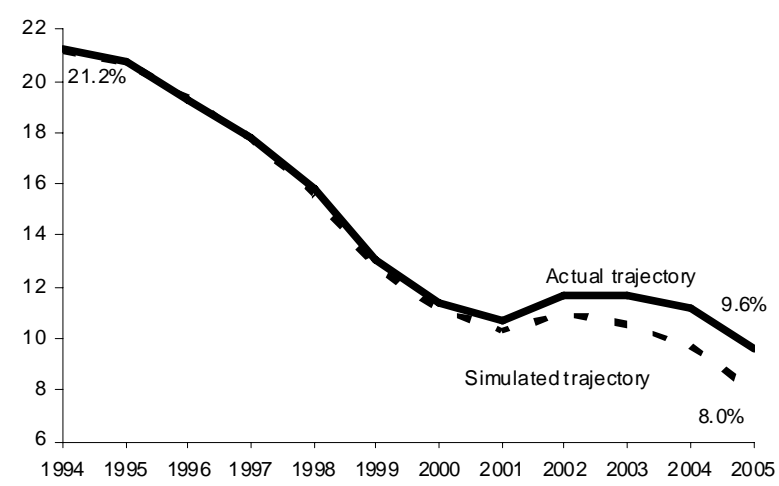

Note: Simulated trajectories result from fixing indirect taxes at years 1977, 1985, 1990 and 1994. 
Figure 6. Financial wealth: evolution and unemployment effects

a. Evolution

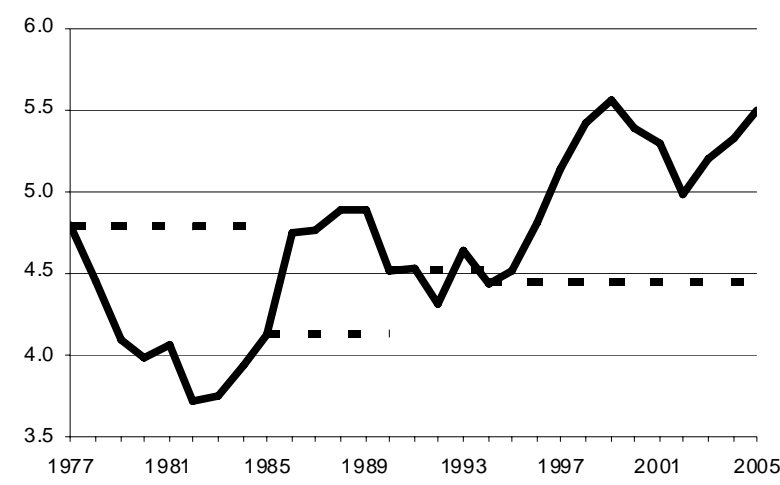

b. $1978-1985$

C. $1986-1990$
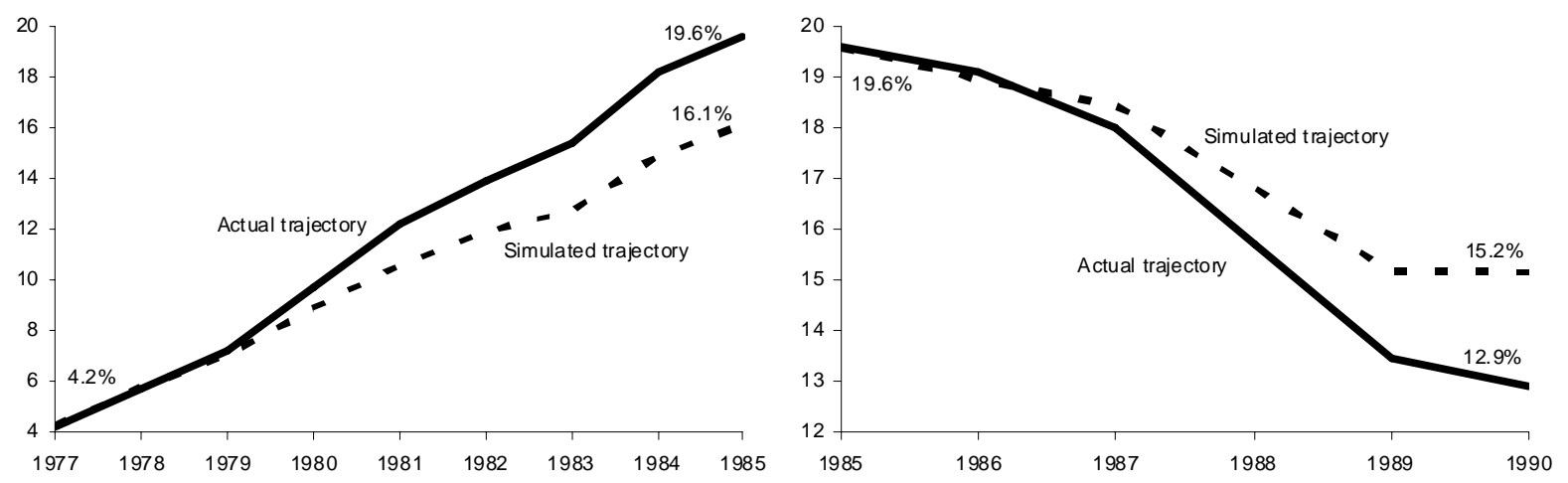

d. 1991-1994

e. $1995-2005$
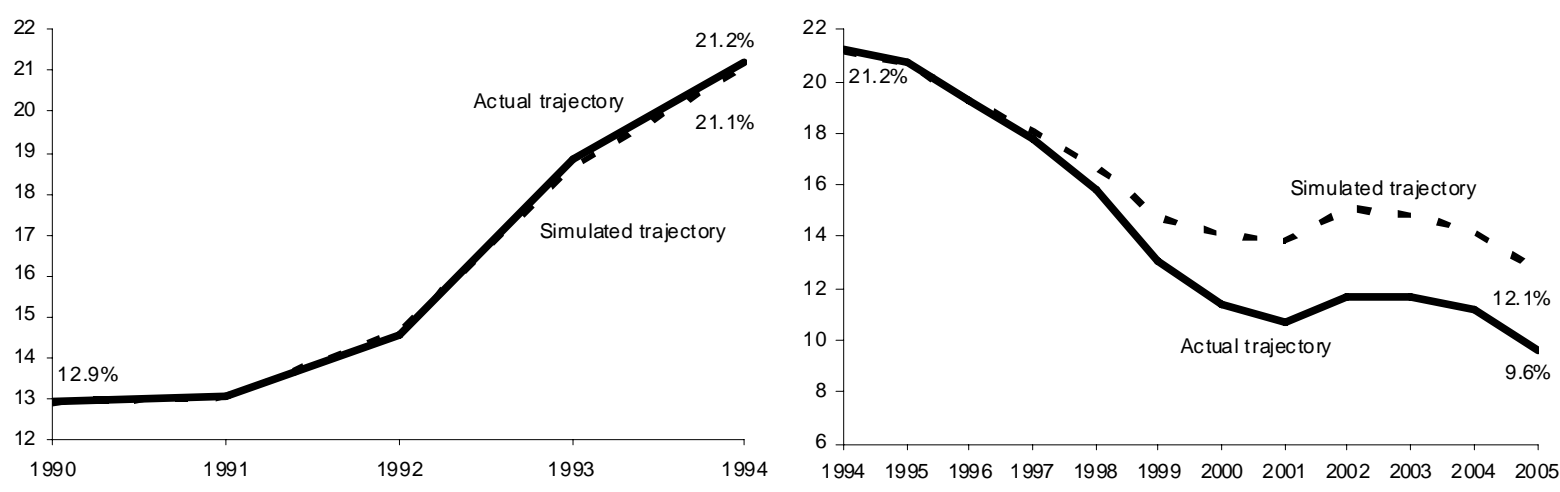

Note: Simulated trajectories result from fixing financial wealth at years 1977, 1985, 1990 and 1994. 
The contributions of foreign demand are depicted in Figure 7 and are qualitatively similar to the contributions of financial wealth. Both variables have an inverse relationship with unemployment and do not contribute to the evolution of the unemployment rate over the 1991-1994 recession. But in contrast to financial wealth, which has an upward trend during the whole sample, foreign demand is characterised by a downward trend. ${ }^{31}$ Furthermore, foreign demand appears to have a stronger impact on the unemployment rate than financial wealth. Had foreign demand stabilised at its value in

- 1977, unemployment would have been 4.2 pp below the 15.4 pp increase over the 1978-1985 recession,

- 1985, unemployment would have been 5.4 pp above the 6.7 pp decrease over the 1986-1991 boom period, and

- 1994, unemployment would have been 5.8 pp above the 11.6 pp decrease over the 1995-2005 boom.

Finally, it is clear from the plots in Figure 8 that capital stock accumulation has the most profound influence on the evolution of the unemployment rate. ${ }^{32}$ In particular,

- Figures 8b, 8c, and 8e show that, for each period, the simulated final value of unemployment is very close to its initial actual value. This indicates that (i) the rise in unemployment during the 1978-1985 "long recession" years, (ii) the fall in unemployment during the 1986-1991"EU cycle" boom period, and (iii) the fall in unemployment during the 1995-2005 "EMU cycle" boom years were mostly due to the swings in the growth rate of capital stock.

- Figure 8d shows that had the capital stock growth remained constant at its 1990 value, unemployment would have been $6.6 \mathrm{pp}$ below the $8.3 \mathrm{pp}$ increase over the 1991-1994 "EU cycle" recession years.

\footnotetext{
${ }^{31}$ In fact, Spain faces a trade deficit since the late 80 s which deteriorates over time.

${ }^{32}$ Bande and Karanassou (2008) examine the dynamics of Spanish regional unemployment rates over the 1980-1995 period and find that capital stock growth was the main driving force of the unemployment rate during the 1985-1991 boom and 1991-1995 recession years.
} 
Figure 7. Foreign demand: evolution and unemployment effects

a. Evolution

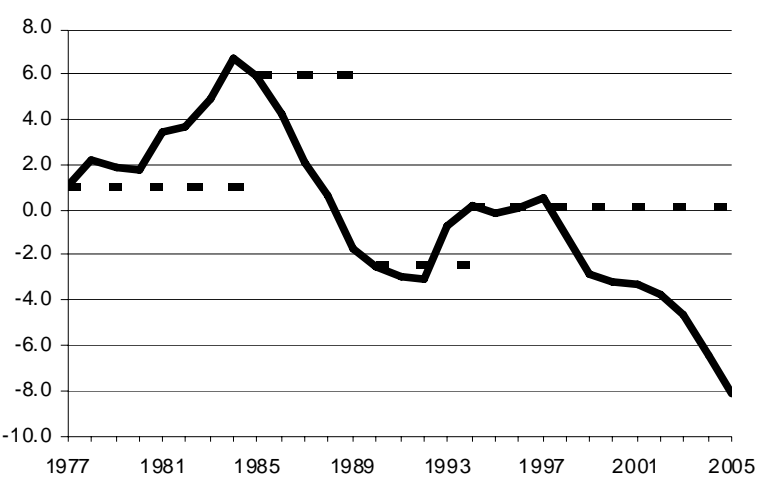

b. $1978-1985$

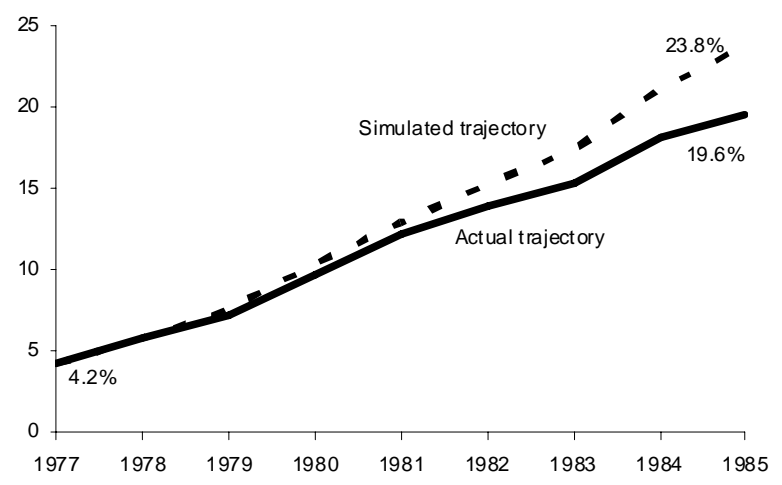

c. $1991-1994$

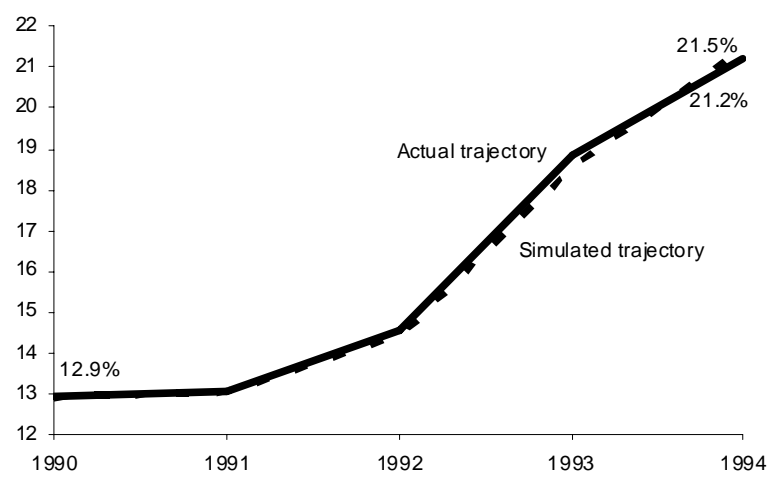

c. $1986-1990$

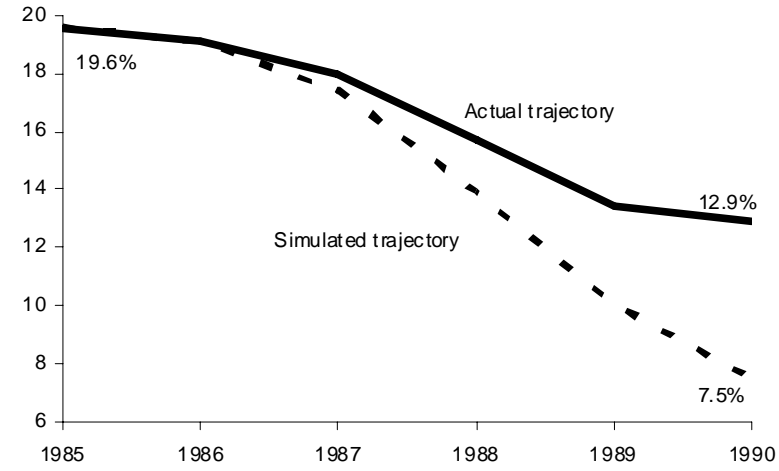

d. $1995-2006$

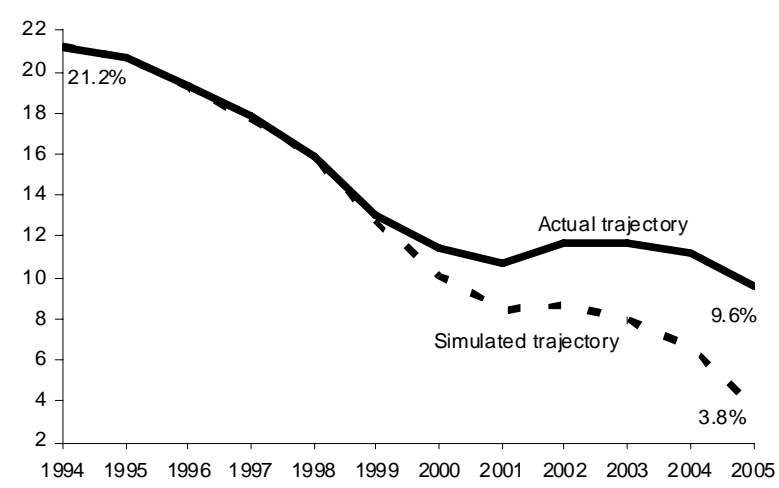

Note: Simulated trajectories result from fixing foreign demand at years 1977, 1985, 1990 and 1994. 
Figure 8. Capital stock accumulation: evolution and unemployment effects

a. Evolution

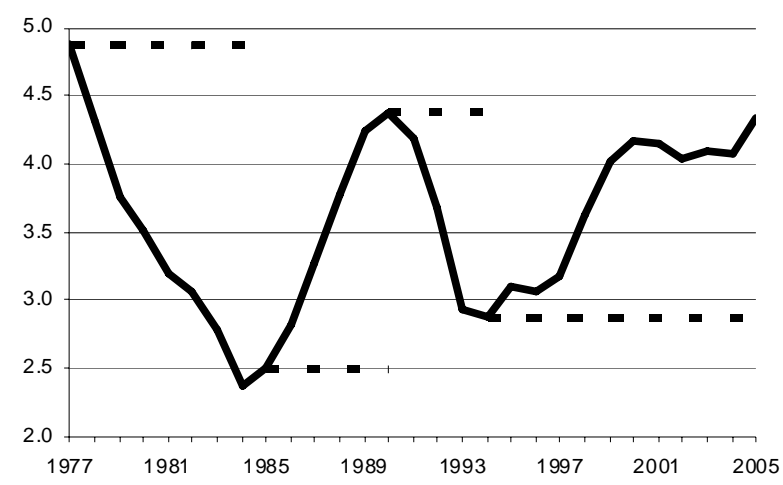

b. $1978-1985$

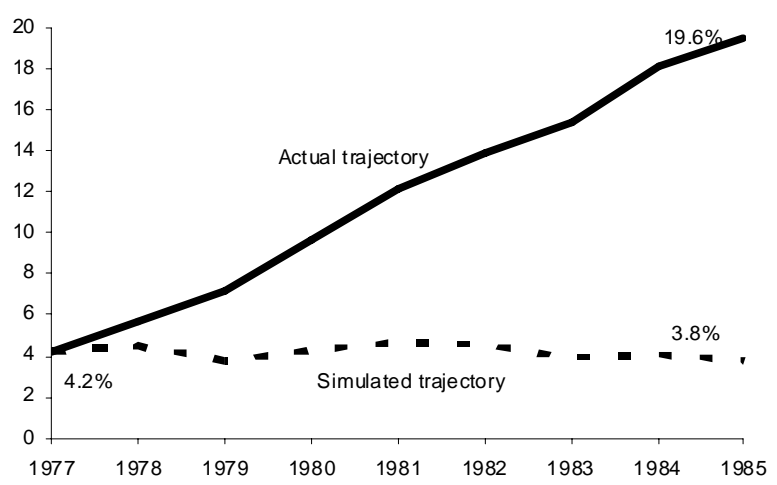

d. $1991-1994$

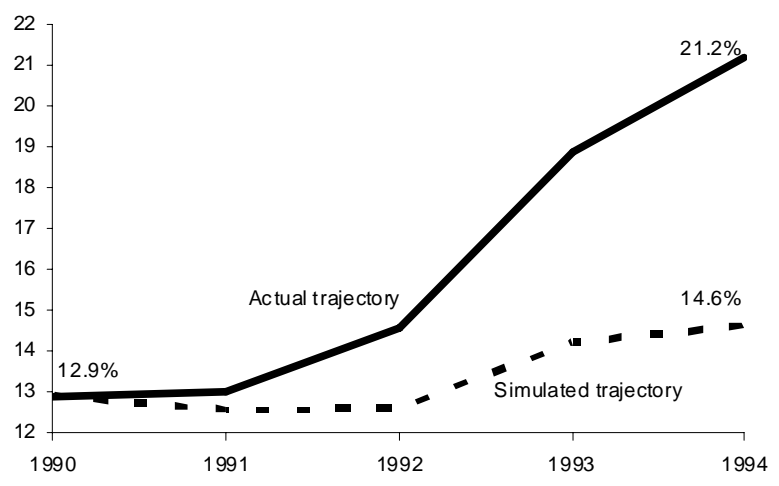

c. $1986-1990$

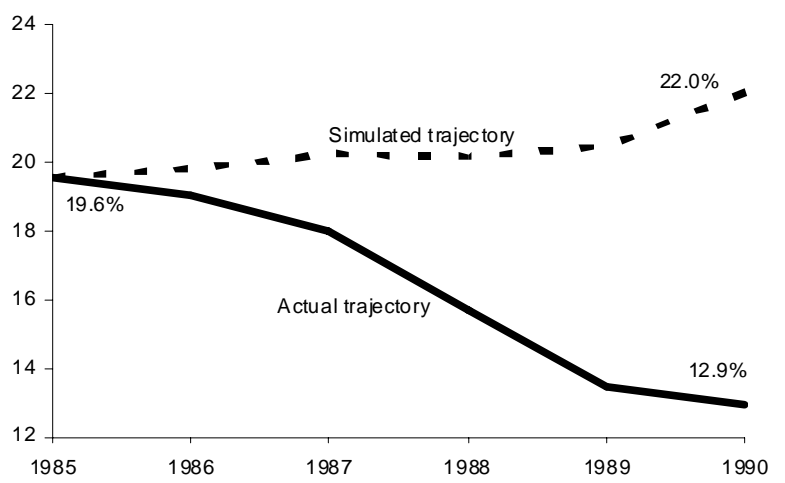

e. $1995-2005$

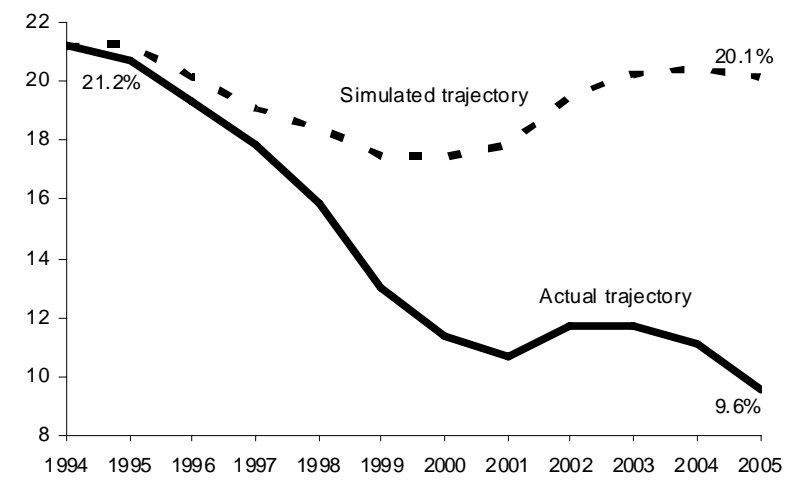

Note: Simulated trajectories result from fixing capital stock accumulation at years 1977, 1985, 1990 and 1994. 


\section{Regime Changes in Capital Accumulation}

The simulations in the previous section showed that capital accumulation is the most crucial factor in driving the unemployment movements over each of the four distinct periods in our sample. In what follows we elaborate on this finding by evaluating the impact of the regime changes in the growth rate of capital stock on the unemployment rate trajectory. We identify the number and longevity of the regimes embedded in the growth rate of the capital stock by estimating its kernel density function. ${ }^{33}$

A stationary time series with different regimes is characterised by a multimodal density of its frequency distribution, the number of modes corresponding to the number of regimes. In particular, a unimodal kernel density indicates that a unique regime exists with mean equal to the value of the mode. On the other hand, a variable with two regimes displays a bimodal kernel density with a "valley point" dividing the observations in the sample. The data points are grouped in the two regimes depending on whether they lie to the left or to the right of the "valley point". The kernel density analysis of the two-regime case can easily be extended to account for three or more regimes.

Naturally, when the variable is characterised by one regime, this is taken to be permanent. For multimodal kernel densities we distinguish between permanent and temporary regimes and identify them as follows. The variable starts in one regime (say, A) in the beginning of the sample, and then moves to another regime (say, B) at some later point in time. If the variable reverses to regime $\mathrm{A}$ before the end of the sample, then regime $\mathrm{B}$ is temporary and regime $\mathrm{A}$ is permanent. On the other hand, if the variable stays in regime $\mathrm{B}$ by the end of the sample then both regimes are permanent ones.

The bimodal kernel density in Figure 9a indicates that the growth rate of capital stock is characterised by two regimes. According to Figure $9 \mathrm{~b}$ these regimes are permanent, the "high" regime with mean 6.8\% lasts until 1976 when capital stock growth enters the "low" regime with mean $3.7 \%$. This permanent capital accumulation downturn accompanies, strikingly well, the higher unemployment rates since 1978 (see Figure 1).

Finally, 1978 onwards, we evaluate the unemployment impact of the permanent decrease in the growth rate of capital stock as follows. We simulate the steady state of the labour market model (in Tables 3-5) under two scenarios over the 1978-2005 period: (i) capital stock growing at $6.8 \%$, and (ii) capital stock growing at $3.7 \%$. The reason for simulating the steady-state of the model is that we want to measure the effect of the permanent shift in the growth rate of the capital stock net of the lagged adjustments present in the labour market. The difference between the two simulated time paths of the

\footnotetext{
${ }^{33}$ Raurich, Sala and Sorolla (2006), for the EU and the US, and Karanassou, Sala, and Salvador (2008b), for the Nordic countries, use the kernel density analysis to evaluate the relationship of unemployment and capital accumulation.
} 
unemployment rate, of around 7 percentage points, is our measure of the long-run contribution of the permanent decline in capital accumulation after 1978 to unemployment. We subtract this contribution from the actual unemployment rate and plot the resulting series in Figure 10 (dotted line).

Figure 9. Regime changes in unemployment and capital stock accumulation a. Kernel density analysis on capital stock accumulation

b. Capital stock accumulation
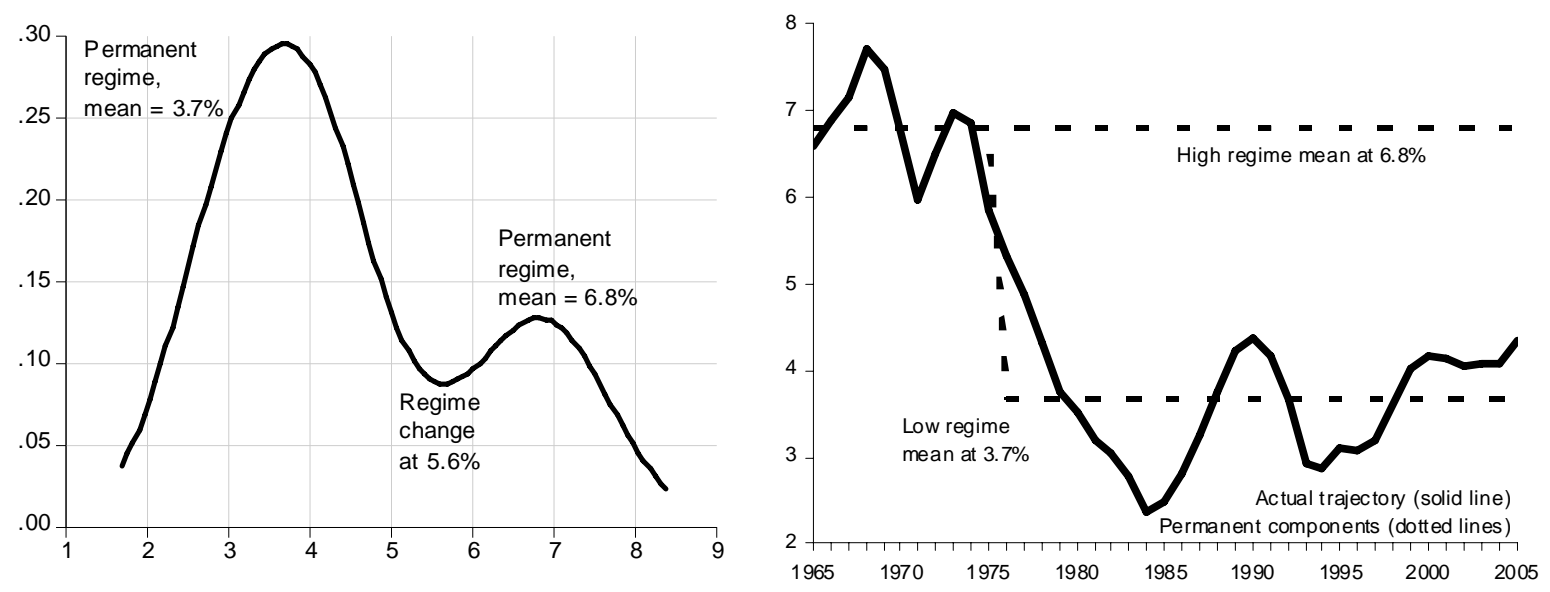

Figure 10 shows that had capital stock growth remained at its high regime mean, unemployment would have peaked at $12.5 \%$ in 1985 instead of the actual 19.6\%. In turn, the actual subsequent fall to around $9.6 \%$ in 2005 would have ended up near $2.6 \%$. This result implies that, in the absence of the permanent slowdown in investment after 1978, Spain would have recovered the full-employment levels that had historically characterised its labour market.

Figure 10. Long-run impact on unemployment of the regime change in capital stock accumulation

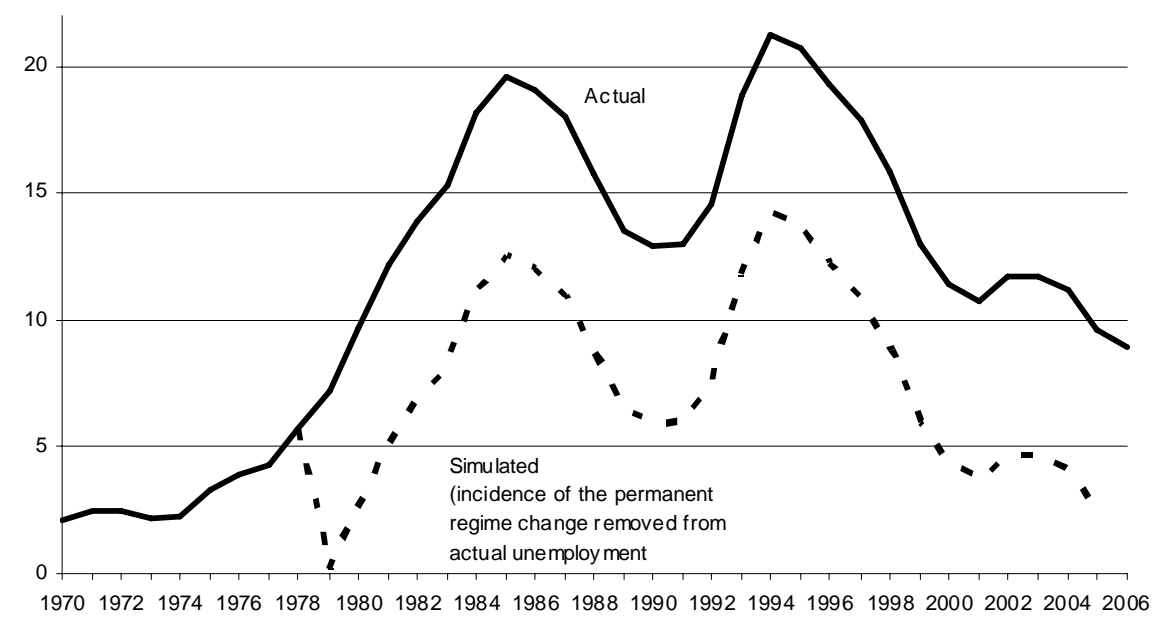




\section{Conclusions}

In this paper we analysed the chain reaction theory (CRT) of unemployment through a stylised labour market model, and showed that the interplay of the dynamics and spillovers in the multi-equation system give rise to the phenomenon of frictional growth. The implications of frictional growth are:

1. unemployment does not gravitate towards its natural rate, since the long-run unemployment rate equals its NRU plus frictional growth;

2. the unemployment rate cannot be decomposed into cyclical (short-run) and "trend" (long-run) components;

3. trended exogenous variables can be included in CRT models and, thus, are allowed to influence the unemployment rate trajectory.

We applied the CRT to the Spanish economy over the 1970-2005 period by estimating a dynamic system of labour demand, real wage, and labour supply equations with spillover effects. We found that, although variables which are among the conventional wisdom's favourite causes of unemployment (i.e. social security contributions, indirect taxes, and financial wealth) do matter, capital accumulation is the most important driving force of unemployment. Furthermore, foreign demand had a substantial impact on the ups and downs of unemployment, especially during the "EU cycle" of 1986-1990 and the "EMU cycle" of 1995-2005.

The finding of capital stock growth as the main determinant of the unemployment rate is in tandem with reality (see Figure 11), and supports the literature on the role of capital accumulation in the evolution of unemployment (Rowthorn, 1995, 1999; Gordon, 1997; Arestis and Biefang-Frisancho Mariscal, 2000; Karanassou and Snower, 2004; Blanchard, 2005; Arestis, Baddeley and Sawyer, 2007; and Karanassou, Sala and Salvador, 2008b).

\section{Figure 11. Actual capital-unemployment relationship}

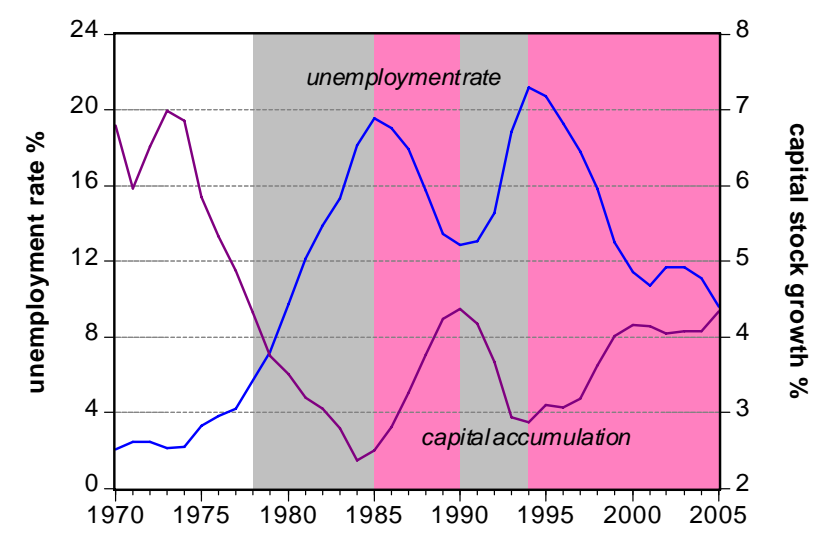


Our findings indicate that the preoccupation of macroeconomists with the estimation of the NRU, quite often serves as an end to itself and does not provide the means to understand what really matters for the evolution of unemployment. We argue that the unemployment problem can be better addressed by estimating CRT models, and measuring the unemployment contributions of the "usual suspects" (e.g. wage-push factors) along with those of growing exogenous variables (such as capital stock).

\section{References}

[1] Arestis, P. and Biefang-Frisancho Mariscal, I. (2000): "Capital stock, unemployment and wages in the UK and Germany", Scottish Journal of Political Economy, vol. 47 (5), pp. 487-503.

[2] Arestis, P., Baddeley, M. and Sawyer, M. (2007): "The relationship between capital stock, unemployment and wages in nine EMU countries", Bulletin of Economic Research, vol. 59 (2), pp. 125-148.

[3] Bande, R. and Karanassou, M. (2008): "Labour market flexibility and regional unemployment rate dynamics: Spain 1980-1995," Papers in Regional Science, forthcoming, doi:10.1111/j.1435-5957.2008.00165.x.

[4] Bentolila, S. and O.J. Blanchard (1990): "Spanish unemployment", Economic Policy, vol. 10, pp. 233-281.

[5] Blanchard, O. (2005): "Monetary policy and unemployment", in Semmler. W. (ed.), Monetary Policy and Unemployment - US, Euro-Area, and Japan, Routledge, London.

[6] Blanchard, O.J. and J. Wolfers (2000): "The Role of Shocks and Institutions in the Rise of European Unemployment: The Aggregate Evidence", The Economic Journal, 110, March.

[7] Cross R., J. Darby, J. Ireland, and L. Piscitelli (1999): "Hysteresis and unemployment: a preliminary investigation", Computing in Economics and Finance, 5th International Conference, Boston.

[8] Dolado, J.J., C. García-Serrano and J.F. Jimeno (2002): "Drawing lessons from the boom of temporary jobs in Spain", The Economic Journal, vol. 112 (480), pp. F270-F295.

[9] Dolado, J.J. and J.F. Jimeno (1997): "The Causes of Spanish Unemployment: A Structural VAR Approach", European Economic Review, vol. 41, pp. 1281-1307.

[10] Dolado, J., Malo de Molina, J.L. and Zabalza, A. (1986): "Spanish industrial unemployment: Some explanatory factors", Economica, vol. 53, pp. 313-334.

[11] Eichengreen, B. (2000): "The EMS Crisis in Retrospect", NBER Working Paper No. 8035.

[12] García de Blas, A. (1985): "Unemployment benefits in Spain and other European OECD countries", International Labour Review, vol. 124 (2), pp. 147-160.

[13] Güell, M. and B. Petrongolo (2007): "How binding are legal limits? Transitions from temporary to permanent work in Spain", Labour Economics, vol. 14 (2), pp. 153-183. 
[14] Garrido, L. and L. Toharia (2004): "What does it take to be (counted as) unemployed? The case of Spain", Labour Economics, vol. 11, pp. 507-523.

[15] Karanassou, M., H. Sala and P.F. Salvador (2008a): "The (IR)relevance of the NRU for policy making: The case of Denmark," Scottish Journal of Political Economy, vol. 55 (3), pp. 369-392.

[16] Karanassou, M., H. Sala and P.F. Salvador (2008b): "Capital Accumulation and Unemployment: New Insights on the Nordic Experience", Cambridge Journal of Economics, forthcoming, doi:10.1093/cje/ben022.

[17] Karanassou, M., H. Sala and D.J. Snower (2003): "Unemployment in the European Union: A Dynamic Reappraisal", Economic Modelling, vol. 20 (2), pp. 237-273.

[18] Karanassou M., Sala H., and D. J. Snower (2008): "Phillips Curves and Unemployment Dynamics: A Critique and a Holistic Perspective", Journal of Economic Surveys, forthcoming.

[19] Karanassou, M. and D.J. Snower (2004): "Unemployment Invariance", The German Economic Review, vol. 5 (3), pp. 297-317.

[20] Layard, R., Nickell, S.J. and Jackman, R. (1991): Unemployment: Macroeconomic Performance and the Labour Market, Oxford: Oxford University Press.

[21] Phelps, E. S. (1994): Structural Booms: The Modern Equilibrium Theory of Unemployment, Interest and Assets, Harvard University Press, Cambridge (MA).

[22] Phelps, E. and G. Zoega (2001): "Structural booms: productivity expectations and asset valuations", Economic Policy, vol. 32, April, pp. 85-126.

[23] Pesaran, M.H. and Y. Shin (1999): "An Autoregressive Distributed-Lag Modelling Approach to Cointegration Analysis" in Econometrics and Economic Theory in the Twentieth Century: The Ragnar Frisch Centennial Symposium, edited by Strom, S., Cambridge University Press, pp. 371-413.

[24] Pesaran, M.H., Shin, Y. and Smith, R.J. (2001): "Bounds testing approaches to the analysis of level relationships", Journal of Applied Econometrics, vol. 16, pp. 289-326.

[25] Polo, C. and F. Sancho (1993): "An analysis of Spain's integration in the EEC", Journal of Policy Modeling, vol. 15 (2), pp. 157-178.

[26] Raurich, X., H. Sala and V. Sorolla (2006): "Unemployment, Growth and Fiscal Policy: New Insights on the Hysteresis Hypotheses", Macroeconomic Dynamics, vol. 10 (3), pp. 285-316.

[27] Rowthorn, R. (1995): "Capital formation and unemployment", Oxford Review of Economic Policy, vol. 11 (1), pp. 26-39.

[28] Rowthorn, R. (1999): "Unemployment, wage bargaining and capital-labour substitution", Cambridge Journal of Economics, vol. 23, pp. 413-425.

[29] Sosvilla-Rivero, S. and J.A. Herce (2008): "European cohesion policy and the Spanish economy: A policy discussion case", Journal of Policy Modeling, vol. 30, pp. 559-570. 